\title{
Comprehensive Proteomic Profiling of Pressure Ulcers in Patients with Spinal Cord Injury Identifies a Specific Protein Pattern of Pathology
}

\author{
Montserrat Baldan-Martin, ${ }^{1, \dagger}$ Tatiana Martin-Rojas, ${ }^{1, \dagger}$ \\ Nerea Corbacho-Alonso, ${ }^{1, \dagger}$ Juan Antonio Lopez, \\ Tamara Sastre-Oliva, ${ }^{1}$ Felix Gil-Dones, ${ }^{1}$ Jesus Vazquez, ${ }^{2}$ \\ Jose Manuel Arevalo, ${ }^{3}$ Laura Mourino-Alvarez, ${ }^{1,+}$ \\ and Maria G. Barderas ${ }^{1,+, *}$ \\ Departments of ${ }^{1}$ Vascular Physiopathology and ${ }^{3}$ Plastic Surgery, National Hospital for Paraplegics (HNP), \\ SESCAM, Toledo, Spain. \\ ${ }^{2}$ Cardiovascular Proteomics Laboratory and CIBER-CV, CNIC, Madrid, Spain. \\ †These authors contributed equally to this work. \\ \$These authors contributed equally to this work.
}

Objective: Severe pressure ulcers (PUs) do not respond to conservative wound therapy and need surgical repair. To better understand the pathogenesis and to advance on new therapeutic options, we focused on the proteomic analysis of PU, which offers substantial opportunities to identify significant changes in protein abundance during the course of PU formation in an unbiased manner. Approach: To better define the protein pattern of this pathology, we performed a proteomic approach in which we compare severe PU tissue from spinal cord injury (SCI) patients with control tissue from the same patients.

Results: We found 76 proteins with difference in abundance. Of these, 10 proteins were verified as proteins that define the pathology: antithrombin-III, alpha-1-antitrypsin, kininogen-1, alpha-2-macroglobulin, fibronectin, apolipoprotein A-I, collagen alpha-1 (XII) chain, haptoglobin, apolipoprotein B-100, and complement factor $B$.

Innovation: This is the first study to analyze differential abundance protein of PU tissue from SCI patients using high-throughput protein identification and quantification by tandem mass tags followed by liquid chromatography tandem mass spectrometry.

Conclusion: Differential abundance proteins are mainly involved in tissue regeneration. These proteins might be considered as future therapeutic options to enhance the physiological response and permit cellular repair of damaged tissue.

Keywords: pressure ulcer, spinal cord injury, proteomics, tandem mass tags

\section{INTRODUCTION}

SPINAL CORD INJURY (SCI) is the result of trauma at any level of the spinal cord causing temporary or permanent damage, and has a sig- nificant effect on the patient's physical and psychosocial well-being. ${ }^{1}$ SCI is associated with considerable health care costs, morbidity, and mortality, especially when it reaches

(c) Montserrat Baldan-Martin, et al. 2019; Published by Mary Ann Liebert, Inc. This Open Access article is distributed under the terms of the Creative Commons License (http://creativecommons.org/ licenses/by/4.0), which permits unrestricted use, distribution, and reproduction in any medium, provided the original work is properly cited.

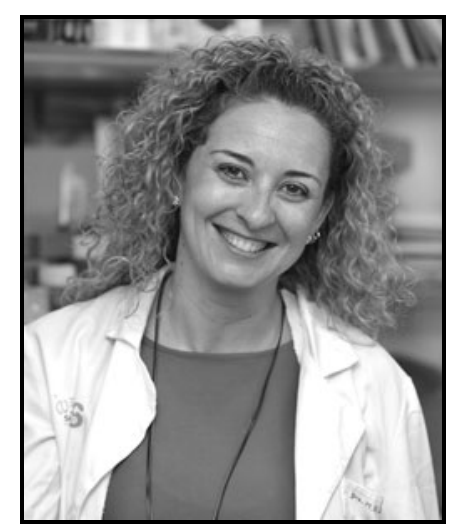

Maria G. Barderas, PhD

Submitted for publication February 14, 2019. Accepted in revised form May 10, 2019.

${ }^{*}$ Correspondence: Department of Vascular Physiopathology, National Hospital for Paraplegics, SESCAM, Edificio de Investigación, la Planta, Laboratorio 3, Toledo 45071, España (e-mail: megonzalezb@sescam.jccm.es; marucitos@hotmail.com). 
advanced stages. Despite advances in health care technology, pressure ulcers (PUs), also called pressure injuries, remain an all too common complication in patients with SCI. PU formation is a complex and poorly understood process, and its prevalence significantly increases with time postinjury. ${ }^{2,3}$ Indeed, recurrence of PUs after healing has been reported to be as high as $35 \%$ for patients with SCI. ${ }^{4}$ PUs are defined as lesions on any skin surface that result from localized shear and/or compression for a prolonged period over bony prominences at certain anatomic locations (e.g., sacrum) ${ }^{5-7}$ This occurrence leads to ischemia of overlying soft tissues that can ultimately result in necrosis. ${ }^{7,8}$ Often, severe PUs (grade 3 or 4 in the grading system, i.e., with full thickness skin loss) do not respond to conservative wound therapy, and surgery is required to prevent further tissue damage. ${ }^{9}$ These limitations in the therapeutic strategies used for PUs underscore the urgent need for new treatments for this serious public health problem.

Although enormous efforts have been expended to better understand the main risk factors for PUs and to improve prevention, the course of these lesions hampers an accurate and individualized evaluation. In accordance, new tools are desirable to further our knowledge on the cellular/molecular subjacent mechanisms of PU development.

Proteomics technologies offer substantial opportunities to identify significant changes in protein abundance during the course of PU formation in an unbiased manner. Advancements in proteomics technology allow the molecular determinants of complex samples like tissue to be analyzed using mass spectrometry (MS). In this study, we describe, for the first time to our knowledge, the protein pattern that defines severe PUs (stages 3 and 4) in SCI patients categorized as grades A and $B$ in the American Spinal Injury Association (ASIA) scale. ${ }^{10}$ We used tandem mass tags (TMT), a powerful and novel method for quantitative proteome analysis developed in recent years utilizing isobaric mass tags, ${ }^{11-13}$ to construct a comparative proteomic profile of $\mathrm{PU}$ and control tissue from the same patients (Fig. 1). The use of these methods can permit the identification of important biological processes that are altered in PU, and may enable the discovery of new therapeutic options to improve clinical management of these patients.

\section{CLINICAL PROBLEM ADDRESSED}

PUs in stages 3 and 4 are a common complication in patients with SCI who do not respond to conservative wound therapy and need surgical repair. ${ }^{9}$
PUs are defined as a lesion on any skin surface that results from pressure or pressure in combination with shear force and/or friction. ${ }^{5-7}$ New tools are desirable to further our knowledge regarding the cellular/molecular subjacent mechanisms of PU development. Advancements in proteomics technology allow the molecular determinants of complex samples like tissue (PUs) to be analyzed using MS.

\section{MATERIALS AND METHODS}

\section{Subject population and design}

Tissue samples were collected from 23 subjects with SCI who were scheduled for PU surgery. For each patient, clinical data including age, sex, smoking status, stage of lesion (3 or 4), ASIA scale scores, and the presence of hypertension, atherosclerosis, dyslipidemia, and diabetes were collected. Exclusion criteria were PUs treated with negative pressure wound therapy, topical growth factors, or dressings containing proteins. The study was approved by the Ethics Committee of the Hospital Nacional de Parapléjicos (Toledo, Spain) and was conducted according to the principles of the Declaration of Helsinki. All patients signed written informed consent before inclusion.

Two different samples were collected from each patient, PU tissue and adjacent tissue as control. Samples were stored in phosphate-buffered saline (PBS) in sterile containers at $4^{\circ} \mathrm{C}$ and processed within a maximum of $2 \mathrm{~h}$ after surgery. Before analysis, samples were washed three times in PBS to reduce blood contaminants.

\section{Histological characterization of ulcer tissues}

For histological characterization, one-third of each tissue was embedded in optimal cutting temperature compound (Thermo Fisher Scientific, Waltham, MA) and sectioned at $8 \mu \mathrm{m}$. Sections were stained with hematoxylin and eosin (H\&E) to characterize the groups of study. Images were captured with an Olympus BX61 microscope connected to a DP71 color camera (Olympus, Tokyo, Japan).

\section{Proteomics pipeline}

The experimental proteomics strategy consisted of two phases: (1) discovery phase using 12 tissue samples (6 control tissues and 6 PU tissues) analyzed by TMT followed by liquid chromatography tandem MS (LC-MS/MS). (2) Verification phase in an independent cohort of 8 tissue samples (8 controls and 8 PU tissues) by two different orthogonal techniques: western blotting and selected reaction monitoring (SRM). Three samples were used for WB optimization and for histological characterization. 
A

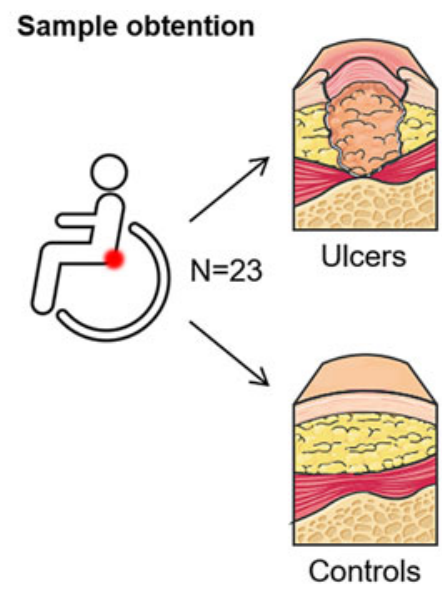

C Discovery phase

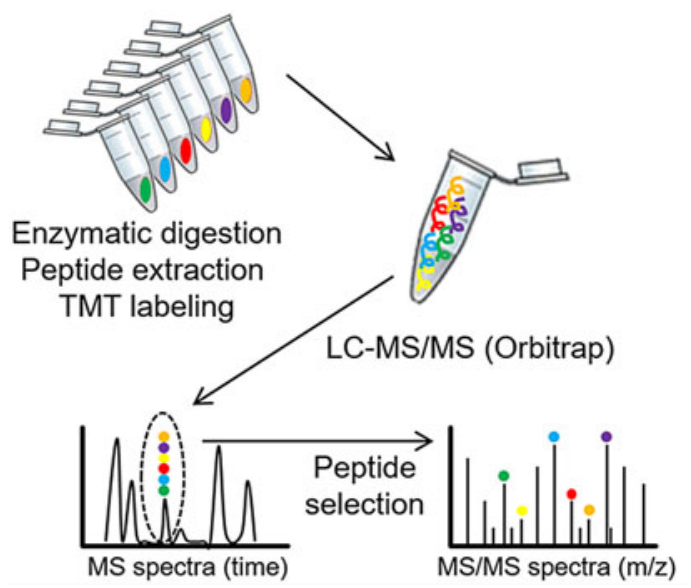

B Histological characterization
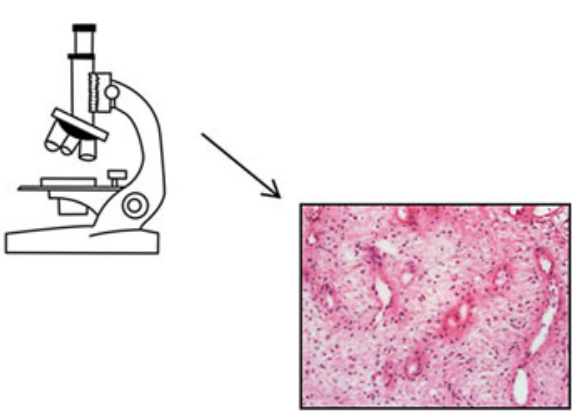

D Verification phase

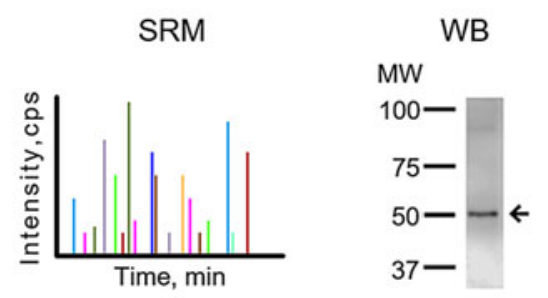

Figure 1. Schematic representation of the workflow. (A) Samples were collected from patients with spinal cord injury. Control and PU tissues were analyzed from the same patient. (B) Hematoxylin and eosin staining was performed to evaluate the morphological changes in the samples. (C) Discovery phase was performed using TMT labeling followed by LC-MS/MS. (D) Verification phase was performed with an independent cohort of patients and employing two orthogonal techniques, SRM and western blotting (WB). LC-MS/MS, liquid chromatography tandem mass spectrometry; PU, pressure ulcer; SRM, selected reaction monitoring; TMT, tandem mass tags. Color images are available online.

\section{Sample preparation for proteomic analysis}

For the discovery phase, tissue samples were cut into small pieces of $\sim 5 \mathrm{~mm}^{2}$ and placed inside centrifuge tubes containing ceramic beads (Roche, Penzberg, Germany) and $200 \mu \mathrm{L}$ of lysis buffer (100 mM Tris $\mathrm{pH} 7.5,1 \%$ sodium dodecyl sulfate [SDS] and $50 \mathrm{mM}$ iodoacetamide [IAA]; SigmaAldrich, Madrid, Spain). Samples were then homogenized at $6,000 \mathrm{rpm} / \mathrm{min}$ for three cycles of 1 min using the MagNA Lyser Instrument (Roche Diagnostics GmbH, Mannheim, Germany). The lysate was then incubated for $5 \mathrm{~min}$ at $100^{\circ} \mathrm{C}$, centrifuged at $18,000 \mathrm{~g}$ for $2 \mathrm{~min}$, and the supernatant collected and incubated at room temperature for $10 \mathrm{~min}$ with shaking. Subsequently, samples were centrifuged at $18,000 \mathrm{~g}$ for $10 \mathrm{~min}$ and the supernatant was saved and assayed for protein concentration using the RC/DC Protein assay kit (Bio-Rad, Hercules, CA).
For the verification phase, tissue samples were ground into powder in liquid nitrogen with a mortar and $0.1-0.2 \mathrm{~g}$ was resuspended in $150-250 \mu \mathrm{L}$ of protein extraction buffer ( $7 \mathrm{M}$ urea, $2 \mathrm{M}$ thiourea, $4 \% \mathrm{w} / \mathrm{v}$ CHAPS). The homogenate was sonicated in cycles of $2 \mathrm{~min}$ and then centrifuged at $18,000 \mathrm{~g}$ for $30 \mathrm{~min}$ at $4^{\circ} \mathrm{C}$. The supernatant from this step was centrifuged at $14,000 \mathrm{~g}$ through a $0.22 \mu \mathrm{m}$ pore size filter tube (Costar Spin-X Centrifuge Tube; Corning, Corning, NY) at $4^{\circ} \mathrm{C}$ to eliminate cellular debris and lipids. The protein concentration of the supernatant was determined by the Bradford-Lowry method (Bio-Rad Protein Assay).

\section{Protein digestion and isobaric labeling}

We used a previously described protocol, ${ }^{14}$ with minor modifications. Quantitative differential LCMS/MS analysis using TMT 10-plex isobaric labeling was developed with $100 \mu \mathrm{g}$ of total protein, 
which was digested by the FASP protocol described previously, ${ }^{15}$ with minor adjustments. Samples were denatured by boiling for $5 \mathrm{~min}$ in $0.2 \% \mathrm{SDS}$, $50 \mathrm{mM}$ IAA, and after incubating in the dark for $30 \mathrm{~min}$ at room temperature. Samples were then diluted in $7 \mathrm{M}$ urea in $0.1 \mathrm{M}$ Tris- $\mathrm{HCl}(\mathrm{pH}$ 8.5; UA buffer) and loaded onto $10 \mathrm{kDa}$ centrifugal filter devices (NanoSep 10k Omega; Pall Life Sciences, Ann Arbor, MI). Buffer was replaced by washing the filters with UA buffer and proteins were then reduced for $30 \mathrm{~min}$ with $10 \mathrm{mM}$ Tris(2-carboxyethyl) phosphine hydrochloride (TCEP; Pierce, Rockford, IL), washed with $50 \mathrm{mM}$ HEPES buffer, and alkylated for $20 \mathrm{~min}$ in the dark in $50 \mathrm{mM}$ methyl methanethiosulfonate (MMTS; Pierce) in UA. Excess alkylating reagent was eliminated by washing three times with UA and further three times with $50 \mathrm{mM}$ ammonium bicarbonate. Proteins were digested overnight at $37^{\circ} \mathrm{C}$ with modified trypsin (30:1 protein:trypsin $[\mathrm{w} / \mathrm{w}]$ in $50 \mathrm{mM}$ ammonium bicarbonate; Promega Corp., Madison, WI). The resulting peptides were twice eluted by centrifugation with $50 \mathrm{mM}$ ammonium bicarbonate and $0.5 \mathrm{M}$ sodium chloride. Trifluoroacetic acid (TFA) was added to a final concentration of $1 \%$ and the peptides were desalted onto C18 Oasis-HLB cartridges (Waters, Milford, MA) and dried-down for further analysis.

For stable isobaric labeling, the resulting tryptic peptides were dissolved in $100 \mathrm{mM}$ triethylammonium bicarbonate (TEAB) buffer, and the peptide concentration was determined by measuring the amide bonds with the Direct Detect system (Millipore, Billerica, MA). Equal amounts of each peptide sample were labeled using 10-plex TMT Reagents (Thermo Fisher Scientific, Rockford, IL) previously reconstituted with $70 \mu \mathrm{L}$ of acetonitrile (ACN) and, after incubation at room temperature for $2 \mathrm{~h}$, the reaction was stopped by adding $0.5 \%$ TFA for 30 min. Samples were concentrated in a Speed Vac, desalted onto C18 Oasis-HLB cartridges and drieddown for further analysis. To increase proteome coverage, TMT-labeled samples were fractionated by high-pH reverse phase chromatography (High pH Reversed-Phase Peptide Fractionation Kit; Pierce) and concentrated as before.

\section{Protein identification and quantitation}

Labeled peptides were analyzed by LC-MS/MS as previously reported. ${ }^{14}$ We used a C-18 reversed phase nano-column $(75 \mu \mathrm{m}$ I.D. $\times 50 \mathrm{~cm}, 2 \mu \mathrm{m}$ particle size, Acclaim PepMap RSLC, 100 C18; Thermo Fisher Scientific, Waltham, MA) with a continuous ACN gradient consisting of $0-30 \% \mathrm{~B}$ in $360 \mathrm{~min}$ and $50-90 \% \mathrm{~B}$ in $3 \mathrm{~min}(\mathrm{~A}=0.1 \%$ formic acid [FA]; $\mathrm{B}=90 \% \mathrm{ACN}, 0.1 \% \mathrm{FA}$ ). A flow rate of $200 \mathrm{~nL} / \mathrm{min}$ was used to elute peptides from the nano-column to an emitter nanospray needle for real-time ionization and peptide fragmentation on an Orbitrap Fusion mass spectrometer (Thermo Fisher Scientific, Waltham, MA). An enhanced FT-resolution spectrum (resolution $=70,000$ ) followed by the MS/ MS spectra from the Nth most intense parent ions were analyzed along the chromatographic run. Dynamic exclusion was set at $40 \mathrm{~s}$. For peptide identification, all spectra were analyzed with Proteome Discoverer (version 2.1.0.81; Thermo Fisher Scientific, Waltham, MA) using SEQUEST-HT (Thermo Fisher Scientific, Waltham, MA). For database searching at the UniProtKB/TrEMBL database containing all sequences from human and contaminants (May 14, 2016; 70,611 entries), the following parameters were selected: trypsin digestion with two maximum missed cleavage sites, precursor and fragment mass tolerances of 2 and $0.02 \mathrm{Da}$, respectively, TMT modifications at $\mathrm{N}$ terminal and Lys residues as fixed modifications, and methionine oxidation, carbamidomethyl cysteine, and MMTS modified cysteine as dynamic modification. Peptide identification was performed using the probability ratio method, ${ }^{16}$ and the false discovery rate (FDR) was calculated using inverted databases and the refined method, ${ }^{17}$ with an additional filtering for precursor mass tolerance of $15 \mathrm{ppm} .{ }^{18}$ Identified peptides had an FDR $\leq 1 \%$. Only those peptides were used to quantify the relative abundance of each protein from reporter ion intensities. Statistical analysis of quantitative data was performed using the weighted spectrum peptide and the protein (WSPP) statistical model previously described. ${ }^{11}$ In this model, the protein log2ratios are expressed as standardized variables, that is, in units of standard deviation according to their estimated variances ( $\mathrm{Zq}$ values).

\section{Western blotting}

Protein samples obtained from PU and control tissues were resolved by $12 \%$ SDS-polyacrylamide gel electrophoresis using a Bio-Rad Miniprotean II electrophoresis cell run at a constant current of $25 \mathrm{~mA} /$ gel. After electrophoresis, the proteins were transferred to a nitrocellulose membrane under a constant voltage of $12 \mathrm{~V}$ for $60 \mathrm{~min}$, which was then stained with Ponceau S. The membranes were then blocked for $1 \mathrm{~h}$ with PBS-T containing 2.5\% nonfat dry milk and 5\% bovine serum albumin (BSA). Membranes were incubated overnight with the primary antibody in PBS-T with $2 \%$ BSA. The primary antibodies used were rabbit polyclonal antisera against haptoglobin (HPT) (ab85846) (1/ 10,000) and alpha-1-antitrypsin (A1AT) (ab207303) 
$(1 / 2,500)$ (both from Abcam, Cambridge, United Kingdom). After washing, the membranes were incubated with a specific horseradish peroxidaseconjugated secondary antibody in PBS-T containing $2 \%$ BSA. Detection was performed by enhanced chemiluminescence (ECL; GE Healthcare, Little Chalfont, United Kingdom). Densitometry was performed with ImageQuantTL software (GE Healthcare).

\section{Selected reaction monitoring}

Following our previously published protocol, ${ }^{19,20}$ samples were reduced with $100 \mathrm{nM}$ dithiothreitol (Sigma-Aldrich) in $50 \mathrm{mM}$ ammonium bicarbonate (99\% purity; Scharlau, Barcelona, Spain) for $30 \mathrm{~min}$ at $37^{\circ} \mathrm{C}$ and alkylated with $550 \mathrm{mM}$ IAA in $50 \mathrm{mM}$ ammonium bicarbonate for $20 \mathrm{~min}$ at room temperature. The proteins were digested in $50 \mathrm{mM}$ ammonium bicarbonate, 15\% ACN (LC-MS grade; Scharlau) with sequencing grade modified porcine trypsin (Promega Corp.) at a final concentration of 1:50. After digestion at $37^{\circ} \mathrm{C}$ overnight, $2 \% \mathrm{FA}$ (99.5\% purity; Sigma-Aldrich) was added and samples were cleaned with Pep-Clean spin columns (Pierce). Tryptic digests were dried in a Speed Vac and resuspended in 2\% ACN, 2\% FA before MS analysis. The LC-MS/MS system consisted of a TEMPO nano LC system (Applied Biosystems, Foster City, CA) combined with a nano LC autosampler and coupled to a modified triple quadrupole MS system (Applied Biosystems 4000 QTRAO $\mathrm{LC} / \mathrm{MS} / \mathrm{MS})$. Three replicate injections $(4 \mu \mathrm{L}$ containing $20 \mu \mathrm{g}$ of protein) were performed per sample using mobile phase A (2\% ACN/98\% water, $0.1 \%$ FA) with a flow rate of $10 \mu \mathrm{L} / \mathrm{min}$ for $5 \mathrm{~min}$. Peptides were loaded onto a $\mu$-Precolumn Cartridge (Acclaim Pep Map 100 C18, $5 \mu \mathrm{m}, 100 \AA$ $300 \mu \mathrm{m}$ I.D. $\times 5 \mathrm{~mm}$; LC Packings, Idstein, Germany) to preconcentrate and desalt samples. Reverse phase LC was achieved on a C18 column (Onyx Monolithic C18, $150 \times 0.1 \mathrm{~mm}$ I.D.; Phenomenex, Torrance, CA) in a gradient of phase A and phase B (98\% ACN/2\% water, $0.1 \%$ FA). Peptides were eluted at a flow rate of $900 \mathrm{~nL} / \mathrm{min}$ in the following steps: $2-15 \% \mathrm{~B}$ for $2 \mathrm{~min}, 15-30 \% \mathrm{~B}$ for $18 \mathrm{~min}, 30-50 \%$ B for $5 \mathrm{~min}, 50-90 \%$ B for $2 \mathrm{~min}$, and finally $90 \% \mathrm{~B}$ for $3 \mathrm{~min}$. The column was then regenerated with $2 \% \mathrm{~B}$ for 15 additional minutes. Both the TEMPO nano LC and 4000 QTRAP system were controlled by Analyst Software v.1.4.5. The mass spectrometer was set to operate in positive ion mode with ion spray voltage of $2,800 \mathrm{~V}$ and a nanoflow interface heater temperature of $150^{\circ} \mathrm{C}$. Source gas 1 and curtain gas were set to 20 and 20 psi, respectively, and nitrogen was applied as both curtain and collision gases. Collision energy was optimized to obtain maximum transmission efficiency and sensitivity for each SRM transition. A total of 94 SRM transitions (2-3 per peptide) were monitored during an individual sample analysis. They were acquired at unit resolution in both Q1 and Q3, with dwell times from 40 to $120 \mathrm{~ms}$, resulting in cycle times of $4.0957 \mathrm{~s}$. The IntelliQuan algorithm, included in Analyst 1.4.5 software, was used to calculate abundances based on peak areas after integration. Differentially expressed peptides were considered as those peptides with at least two of three transitions significant and, in the case of proteins identified by only one peptide, those with the same trend in both peptides.

\section{Functional group analysis}

For functional examination of the identified proteins, a list of the 76 significantly varied proteins was entered into the online software Search Tool for the Retrieval of Interacting Genes/ Proteins (STRING v9.1), for functional and protein interaction analyses.

\section{Statistical analysis}

Statistical analyses were performed using SPSS 15.0 for Windows software (SPSS, Inc., Chicago, IL). Data of patient' characteristics are presented as mean in the case of continuous variables, or percentages in the case of discrete variables such as sex or the presence/absence of risk factors. For the TMT results, we considered proteins differentially expressed if they were identified with at least two peptides and they had log2-ratios expressed in the form of the standardized variables $(\mathrm{Zq}) \pm 1.5$ $(p \leq 0.05)$, with Zq signifying the mean of the six replicates versus the internal standard. The changes in peptide and protein abundance were assessed with a $1 \%$ FDR, using the TMT reporter ion intensities from MS/MS scans from SanXoT software as inputs to the WSPP model. ${ }^{21}$ For SRM analysis, the Kolmogorov-Smirnov test was used to demonstrate normal distribution of data before use of the paired Student's $t$-test. Statistical significance was accepted at $* p<0.05, * * p<0.01, * * * p<0.001$.

\section{RESULTS}

\section{Study population}

During the course of the study, 23 patients were enrolled. The experimental proteomics strategy consisted of two phases: (1) discovery phase using 12 tissue samples ( 6 control tissues and $6 \mathrm{PU}$ tissues) analyzed by TMT followed by LC-MS/MS. (2) Verification phase in an independent cohort of 8 tissue samples ( 8 controls and $8 \mathrm{PU}$ tissues) by two different orthogonal techniques: western blotting 
and SRM. Three samples were used for WB optimization and for histological characterization. All patients presented severe PU (stage 3 or stage 4 ). Detailed clinical characteristics of the patients are given in Table 1.

\section{Histological changes of the severe pressure ulcers}

According to the histological examination by H\&E staining, severe PU tissue samples showed possible inflammatory cells throughout the dermis, taking into account the existence of very important inflammation phase previous to a proliferation phase in PUs and, blood vessels were occluded or barely discernible (Fig. 2). In addition, the extracellular matrix was less dense and open dermal wounds were formed as a result of the pressure produced. By contrast, healthy tissue showed the typical layered structure, with well-packed collagen matrix and well-formed vasculature (Fig. 2).

\section{Proteomic profiling of PU tissue}

The difference in abundance of protein between control and PU tissue was determined using a multiproteomic approach for identification of novel proteins and for further verification. In the discovery phase, samples from six patients (12 tissue samples) were analyzed using TMT-based multiplexed isobaric labeling followed by LC-MS/MS. This analysis allowed us to identify a total of 4,504 proteins, of which 76 showed abundance differences. Detailed information including protein ID, description of protein, $\mathrm{Zq}$ values, and $p$-values are given in Table 2 .

Functional analysis of the proteins with differences in relative abundance was explored using STRING v10.5. According to the molecular function, it was remarkable that a substantial number of proteins were implicated in enzyme regulator activity, including peptidase regulator or lipase inhibitor activity categories (Fig. 3). This group included 20 proteins that were considered for further verification.

\section{A tissue protein pattern comprising 10 proteins reflects $\mathrm{PU}$ pathology}

Our goal was to identify a protein pattern associated with PUs in SCI patients. According to functional analysis, we selected proteins with a role in enzyme regulator activity, including antithrombinIII (ANT3), A1AT, kininogen-1 (KNG1), alpha-2macroglobulin (A2MG), fibronectin (FINC), and apolipoprotein A-I (APOA1). In addition, we selected four proteins with different yet potentially interesting functions in PU pathology: collagen alpha-1 (XII) chain (COCA1), HPT, apolipoprotein B-100 (APOB), and complement factor B (CFAB). All proteins were validated/confirmed using a complementary proteomics approach (SRM), and in an independent cohort of patients $(n=8)$ and control $(n=8)$ samples (Tables 3 and 4 and Fig. 4). Fur-

Table 1. Clinical characteristics of patients recruited for the study

\begin{tabular}{|c|c|c|c|c|c|c|c|c|c|}
\hline Patient & Age & Sex & PU Stage & ASIA Scale & AHT & CAHD & $D M$ & Smoking & $D L$ \\
\hline 1 & 34 & Male & 4 & D4 ASIA A & No & No & No & No & No \\
\hline 2 & 42 & Male & 4 & D7 ASIA A & No & No & No & No & No \\
\hline 3 & 50 & Male & 4 & D8 ASIA D & Yes & No & No & Yes & No \\
\hline 4 & 24 & Male & 4 & D7 ASIA A & No & No & No & Yes & No \\
\hline 5 & 76 & Male & 4 & D4 ASIA A & Yes & Yes & No & No & Yes \\
\hline 6 & 22 & Male & 3 & D11 ASIA A & No & No & No & No & No \\
\hline 7 & 48 & Male & 4 & C4 ASIA B & No & No & No & No & No \\
\hline 8 & 35 & Female & 4 & D5 ASIA A & No & No & Yes & Yes & Yes \\
\hline 9 & 61 & Female & 3 & D4 ASIA A & No & No & No & Yes & No \\
\hline 10 & 28 & Male & 3 & C5 ASIA A & No & No & No & No & Yes \\
\hline 11 & 37 & Male & 4 & D3 ASIA A & No & No & No & No & Yes \\
\hline 12 & 48 & Male & 4 & D2 ASIA B & No & No & Yes & No & Yes \\
\hline 13 & 41 & Male & 4 & C6 ASIA A & No & No & No & No & Yes \\
\hline 14 & 70 & Male & 4 & D10 ASIA A & Yes & No & No & No & Yes \\
\hline 15 & 35 & Female & 4 & D5 ASIA A & No & No & No & Yes & No \\
\hline 16 & 72 & Male & 4 & L1 ASIA A & Yes & No & No & No & No \\
\hline 17 & 66 & Male & 4 & L1 ASIA A & No & No & No & No & No \\
\hline 18 & 47 & Male & 4 & C7 ASIA A & No & No & No & Yes & No \\
\hline 19 & 29 & Male & 4 & C6 ASIA A & No & No & No & No & No \\
\hline 20 & 53 & Female & 4 & C5 ASIA A & No & No & No & No & No \\
\hline 21 & 67 & Male & 3 & D4 ASIA A & Yes & No & No & No & Yes \\
\hline 22 & 56 & Male & 4 & D3 ASIA A & Yes & No & Yes & No & Yes \\
\hline 23 & 39 & Male & 4 & D6 ASIA A & Yes & No & Yes & Yes & No \\
\hline Mean (\%) & 47 & Male, 83 & IV, 83 & $87 \% A, 8.7 \%$ B, $4.3 \% \mathrm{D}$ & $30 \%$ & $4 \%$ & $17 \%$ & $30 \%$ & $39 \%$ \\
\hline
\end{tabular}

AHT, arterial hypertension; ASIA, American Spinal Injury Association; CAHD, coronary artery heart disease; DM: type 2 diabetes mellitus; DL, dyslipidemia; PU, pressure ulcer. 

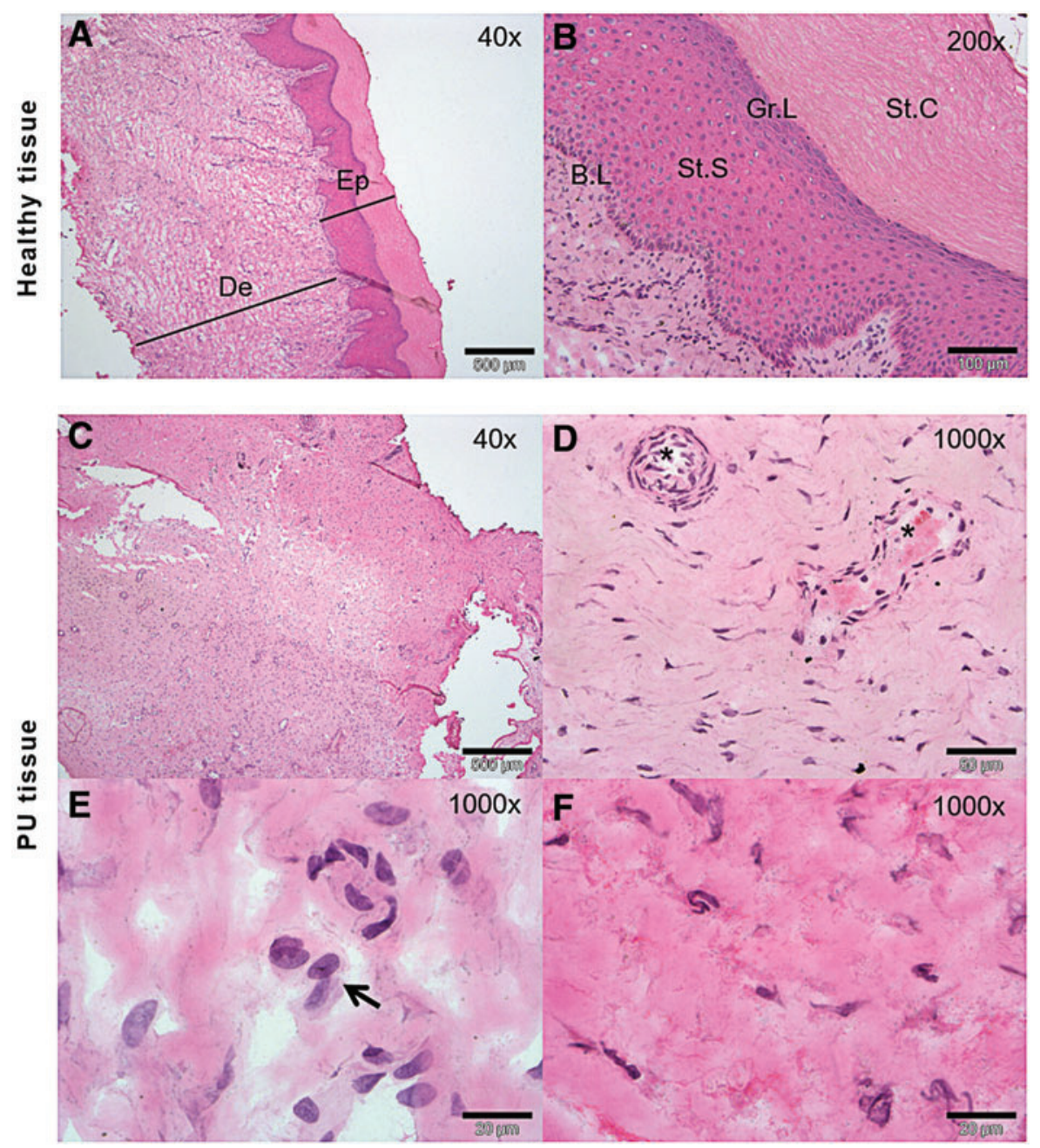

Figure 2. Histological characterization of grade 4 ulcer. (A, D) Control tissue showing the typical layer structure of the skin including epidermis (Ep) and dermis (De). In a larger magnification (D, 200×), stratum corneum (St.C), granular layer (Gr.L), stratum spinosum (St.S) and basal layer (B.L) are shown. (B, C, E and F) Tissue affected by severe PU showing loss of the epidermis layer (C), a less dense extracellular matrix (E, F), numerous inflammatory cells (arrow, E), and occluded blood vessels ( ${ }^{*}$, D). Scale bar corresponds to $500 \mu \mathrm{m}$ in $40 \times$ images, $100 \mu \mathrm{m}$ in $200 \times$ images and $20 \mu \mathrm{m}$ in $1,000 \times$ images. Color images are available online.

thermore, we analyzed the location of the detected peptides in each protein used in SRM analysis. In Fig. 5, we showed that all detected peptides correspond to the mature protein.

To complement these findings, we performed western blotting of two representative proteins, HPT and CFAH, which were both found to be more abundant in PU tissue relative to control tissue ( $p=0.009$ and $p=0.016$, respectively; Fig. 6 ).

\section{DISCUSSION}

The formation of PUs is an important and potentially life-threatening secondary complication of SCI, as they frequently lead to further functional disability and fatal infections, necessitating surgical intervention. ${ }^{22,23}$ The identification of new protein patterns involved in the pathogenesis of
PUs may lead to better treatment management and also to new therapeutic interventions, which would help patients with SCI attain a better quality of life, facilitating their return to daily life. Although proteomics studies have been previously conducted on ulcers, ${ }^{24-26}$ to the best of our knowledge, this is the first proteomics study comparing healthy and PU tissue from patients with SCI, which is important given that the biochemical profile of chronic PU is different between SCI and non-SCI populations. ${ }^{27}$

Great efforts have been made in recent years to understand the mechanisms leading to the development of PUs in patients with SCI, including processes related to hemostasis, inflammation, proliferation, and remodeling. ${ }^{28-30}$ Evidence has shown that the pathological process of PU formation is characterized by increased levels of proin- 
Table 2. Differentially expressed proteins identified by tandem mass tag labeling in pressure ulcer tissue and control tissue

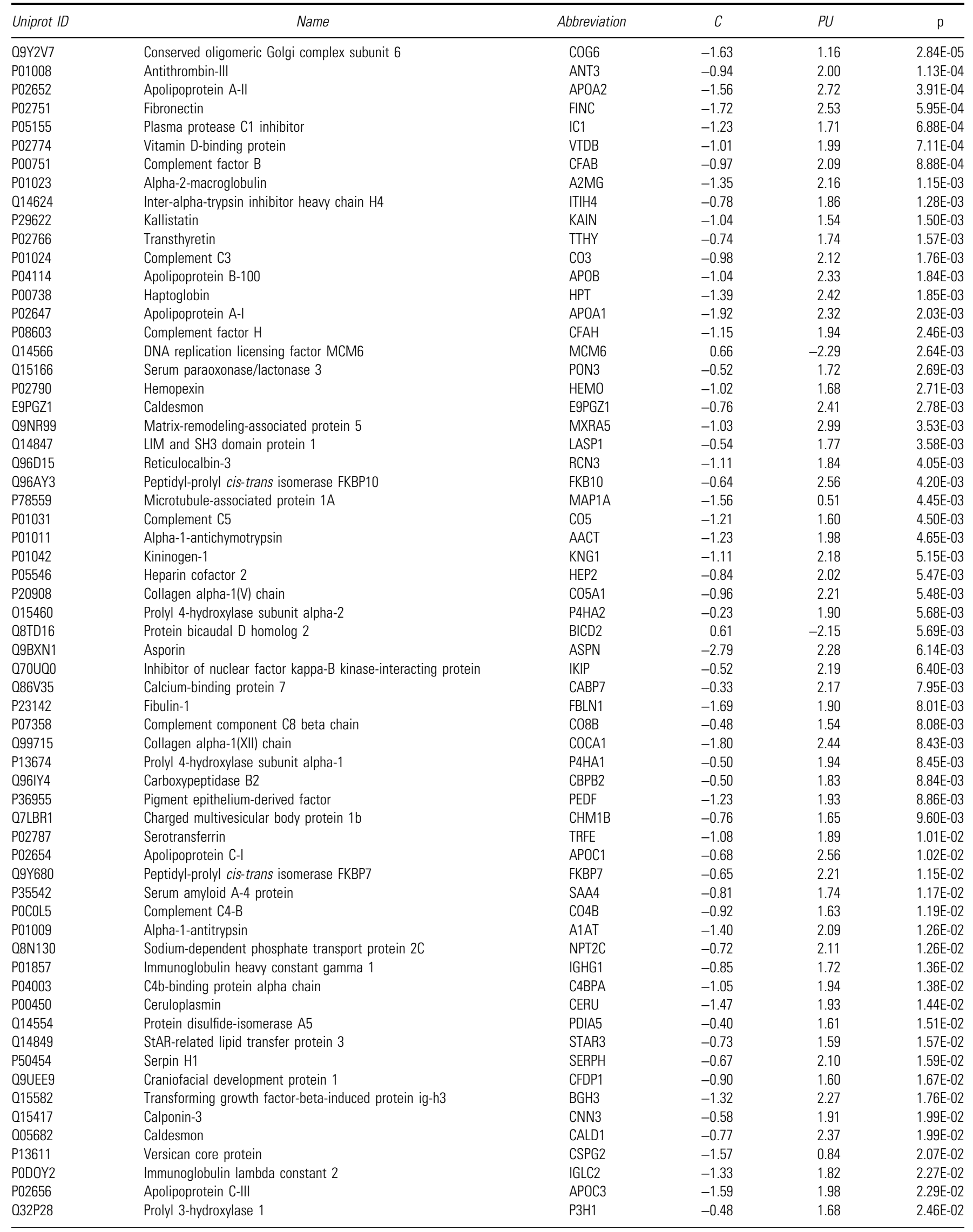


Table 2. (Continued)

\begin{tabular}{|c|c|c|c|c|c|}
\hline Uniprot ID & Name & Abbreviation & C & $P U$ & p \\
\hline P01780 & Immunoglobulin heavy variable 3-7 & HV307 & -1.19 & 2.03 & 2.78E-02 \\
\hline 08TED1 & Probable glutathione peroxidase 8 & GPX8 & -0.43 & 1.62 & 2.96E-02 \\
\hline P36222 & Chitinase-3-like protein 1 & CH3L1 & -0.59 & 1.88 & 3.11E-02 \\
\hline 05TCU3 & Tropomyosin beta chain & 05TCU3 & -1.63 & 1.69 & 3.25E-02 \\
\hline 043488 & Aflatoxin B1 aldehyde reductase member 2 & ARK72 & -1.57 & 0.50 & $3.47 \mathrm{E}-02$ \\
\hline P14735 & Insulin-degrading enzyme & IDE & 0.84 & -1.71 & 3.68E-02 \\
\hline 015293 & Reticulocalbin-1 & RCN1 & -0.94 & 1.86 & 3.74E-02 \\
\hline P02655 & Apolipoprotein C-II & APOC2 & -1.66 & 1.86 & 3.79E-02 \\
\hline P35442 & Thrombospondin-2 & TSP2 & -1.74 & 1.69 & 4.44E-02 \\
\hline Q9UGM5 & Fetuin-B & FETUB & -0.16 & 1.70 & 4.50E-02 \\
\hline Q9P2E9 & Ribosome-binding protein 1 & RRBP1 & -0.50 & 1.59 & 4.70E-02 \\
\hline 016352 & Alpha-internexin & AINX & -0.73 & 1.79 & 4.88E-02 \\
\hline 075478 & Transcriptional adapter 2-alpha & TAD2A & -0.31 & 2.72 & 4.96E-02 \\
\hline
\end{tabular}

$\mathrm{Zq}$ values of controls $(\mathrm{C})$ and ulcers (PU) and $p$-values are given.

flammatory cytokines and proteases, ${ }^{31}$ and also reactive oxygen species, ${ }^{32,33}$ in addition to the development of a cellular senescent phenotype (keratinocytes, endothelial cells, fibroblasts, and macrophages). ${ }^{34-37}$ Moreover, there is a risk for persistent infection and a deficiency of stem cells, which are often also dysfunctional. ${ }^{38-40}$ The precise mechanisms of PU development, however, remain unclear. In this context, our findings may allow for a richer understanding of PU pathophysiology in SCI. Indeed, this is the first study to analyze differential protein abundance of PU tissue from SCI patients using high-throughput protein identification and quantification by TMT followed by LC-MS/MS.

We found a total of 76 proteins with differences in relative abundance between PU and control tissue using TMT labeling. Analysis of molecular function revealed a group of 20 proteins implicated in enzyme regulatory activity that were considered for further analysis. Finally, a group of 10 proteins (with 6 proteins related to enzymatic regulation) was confirmed by the complementary techniques of SRM and/or western blotting.

In relation to the group of six proteins with enzyme regulatory activity, five (A1AT, ANT3, KNG1, A2MG, and FINC) are associated with peptidase regulation, whereas APOA1 has lipase inhibitor activity. The study of the relationship between proteases and wound healing has mainly focused on metalloproteinases and their inhibitors. ${ }^{41-43}$ Of interest, in our study, we also found differences in other types of peptidase inhibitors, such as serine protease inhibitors (serpins) (Fig. 3).

We found more abundance levels of A1AT, a serpin that regulates the recruitment of neutrophils to sites of injury as a response to inflammation, thus acting as an anti-inflammatory and immunoregulatory protein. ${ }^{44}$ Similarly, ANT3 has powerful anti-inflammatory effects and modulates inflammatory responses by inhibiting thrombin and other factors, and by coagulation-independent effects, including direct interaction with cellular mediators of inflammation. ${ }^{45-47}$ The elevated abundance of these proteins could reflect a physiological but insufficient wound healing response. Consistent with this is the finding that an increase in ANT3 abundance favors the amelioration of other type of injuries such as burns. ${ }^{48,49}$ KNG1 has an antiprotease activity in the chronic wound environment ${ }^{50}$ and may undergo degradation, releasing specific proinflammatory peptides named kinins, which mediate vasodilatation, pain, and edema. ${ }^{51-53}$ Destruction of the extracellular matrix was clearly evident in the histological analysis of PU tissue, indicating an inhibition of fibrinolysis produced by inhibitors such as A2MG, which was also more abundant in injured tissue in our analysis. Increased levels of this protein have been reported in chronic ulcer wound fluid and correlate with FINC fragments produced by neutrophil elastases. ${ }^{54}$ FINC is a glycoprotein involved in many cellular mechanisms such as cell growth and migration, ${ }^{55-59}$ and like collagen, contains a number of binding sites for growth factors, including fibroblast growth factor, vascular endothelial growth factor, and platelet-derived growth factor, which have been shown to promote wound healing. ${ }^{60-62}$

With regard to lipase inhibitor activity, we found more abundance of APOA1 in PU compared with control tissue. APOA1 is the major structural component of high-density lipoproteins (HDL), and has anti-inflammatory and immunomodulatory functions in addition to endothelial protective properties. ${ }^{63,64}$ Of interest, a reduction in HDL levels are associated with increased foot ulceration in diabetic patients. ${ }^{65}$ HDL may beneficially impact 


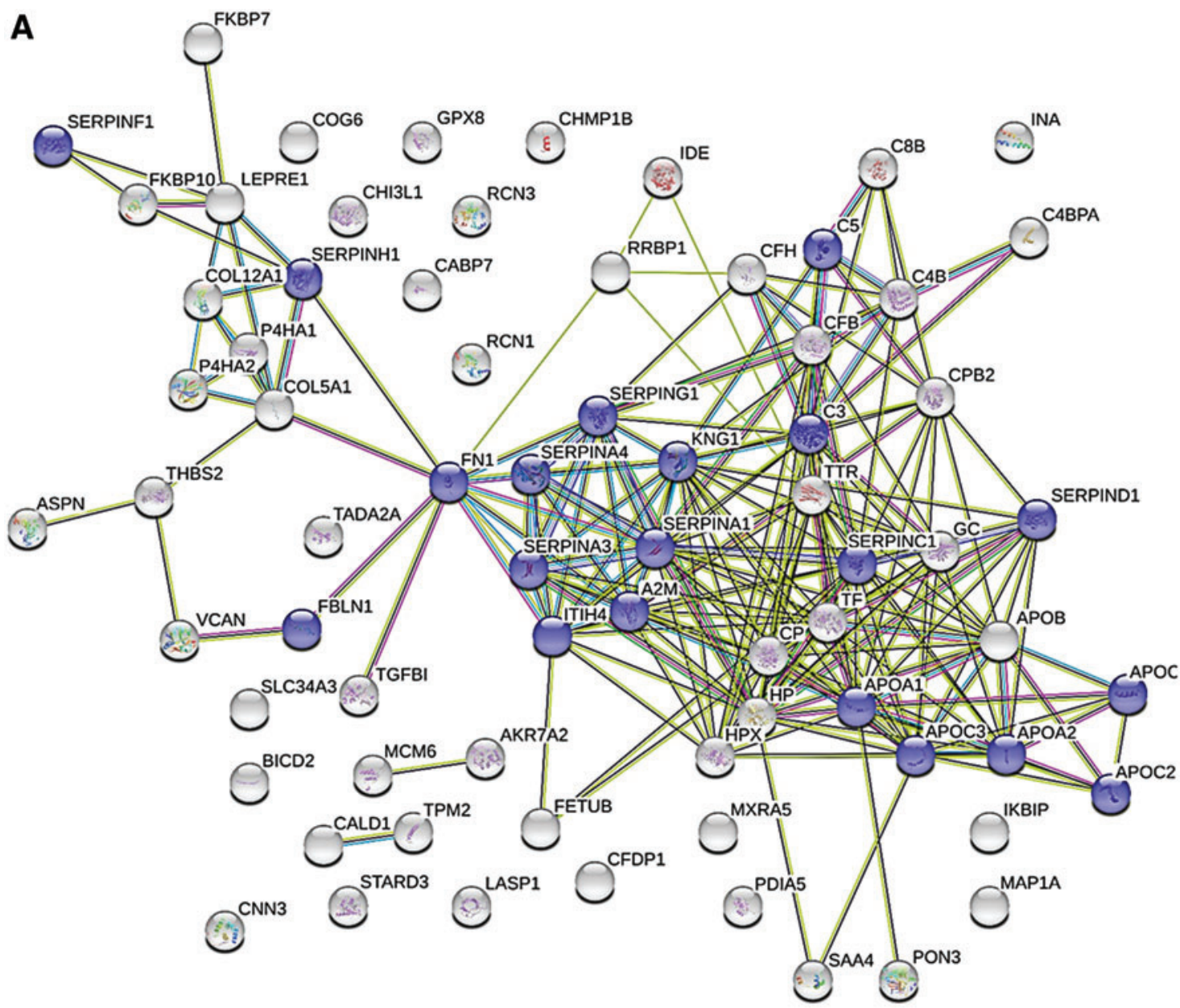

\begin{tabular}{|c|c|c|c|c|}
\hline \#pathway ID & $\begin{array}{c}\text { pathway } \\
\text { description }\end{array}$ & $\begin{array}{l}\text { gene } \\
\text { count }\end{array}$ & FDR & Proteins \\
\hline GO.0004857 & $\begin{array}{l}\text { enzyme } \\
\text { inhibitor } \\
\text { activity }\end{array}$ & 18 & $2.15 \mathrm{E}-13$ & $\begin{array}{l}\text { A2M,APOA1,APOA2,APOC1,APOC2,APOC3,C3, } \\
\text { C5,ITIH4,KNG1,SERPINA1,SERPINA3, } \\
\text { SERPINA4,SERPINC1,SERPIND1, } \\
\text { SERPINF1,SERPING1, SERPINH1 }\end{array}$ \\
\hline Go.0061134 & $\begin{array}{l}\text { peptidase } \\
\text { regulator } \\
\text { activity }\end{array}$ & 15 & 4.18E-13 & $\begin{array}{l}\text { A2M,C3,C5,FBLN1,FN1,ITIH4,KNG1, } \\
\text { SERPINA1,SERPINA3,SERPINA4,SERPINC1, } \\
\text { SERPIND1, SERPINF1,SERPING1,SERPINH1 }\end{array}$ \\
\hline GO.0004866 & $\begin{array}{l}\text { endopeptidase } \\
\text { inhibitor } \\
\text { activity }\end{array}$ & 13 & $1.35 E-11$ & $\begin{array}{c}\text { A2M,C3,C5,ITIH4,KNG1,SERPINA1,SERPINA3, } \\
\text { SERPINA4,SERPINC1,SERPIND1,SERPINF1, } \\
\text { SERPING1,SERPINH1 }\end{array}$ \\
\hline Go.0004867 & $\begin{array}{l}\text { serine-type } \\
\text { endopeptidase } \\
\text { inhibitor } \\
\text { activity }\end{array}$ & 10 & $5.35 \mathrm{E}-10$ & $\begin{array}{l}\text { A2M,ITIH4,SERPINA1,SERPINA3,SERPINA4, } \\
\text { SERPINC1,SERPIND1,SERPINF1,SERPING1, } \\
\text { SERPINH1 }\end{array}$ \\
\hline GO.0030234 & $\begin{array}{l}\text { enzyme } \\
\text { regulator } \\
\text { activity }\end{array}$ & 20 & $3.70 \mathrm{E}-09$ & $\begin{array}{l}\text { A2M,APOA1,APOA2,APOC1,APOC2,APOC3,C3, } \\
\text { C5,FBLN1,FN1,ITIH4,KNG1,SERPINA1, } \\
\text { SERPINA3,SERPINA4,SERPINC1,SERPIND1, } \\
\text { SERPINF1, SERPING1,SERPINH1 }\end{array}$ \\
\hline GO.0055102 & $\begin{array}{l}\text { lipase inhibitor } \\
\text { activity }\end{array}$ & 5 & $9.08 \mathrm{E}-07$ & APOA1,APOA2,APOC1,APOC2,APOC3 \\
\hline
\end{tabular}

Figure 3. Pathway analysis of the differentially expressed proteins. (A) Protein-protein interaction networks were studied with STRING v9.1. Proteins with red circles correspond to proteins with enzyme regulator activity. (B) The six more significant molecular functions according to the classification performed using this tool are shown. Color images are available online. 
Table 3. Results obtained from plasma analyses using selected reaction monitoring

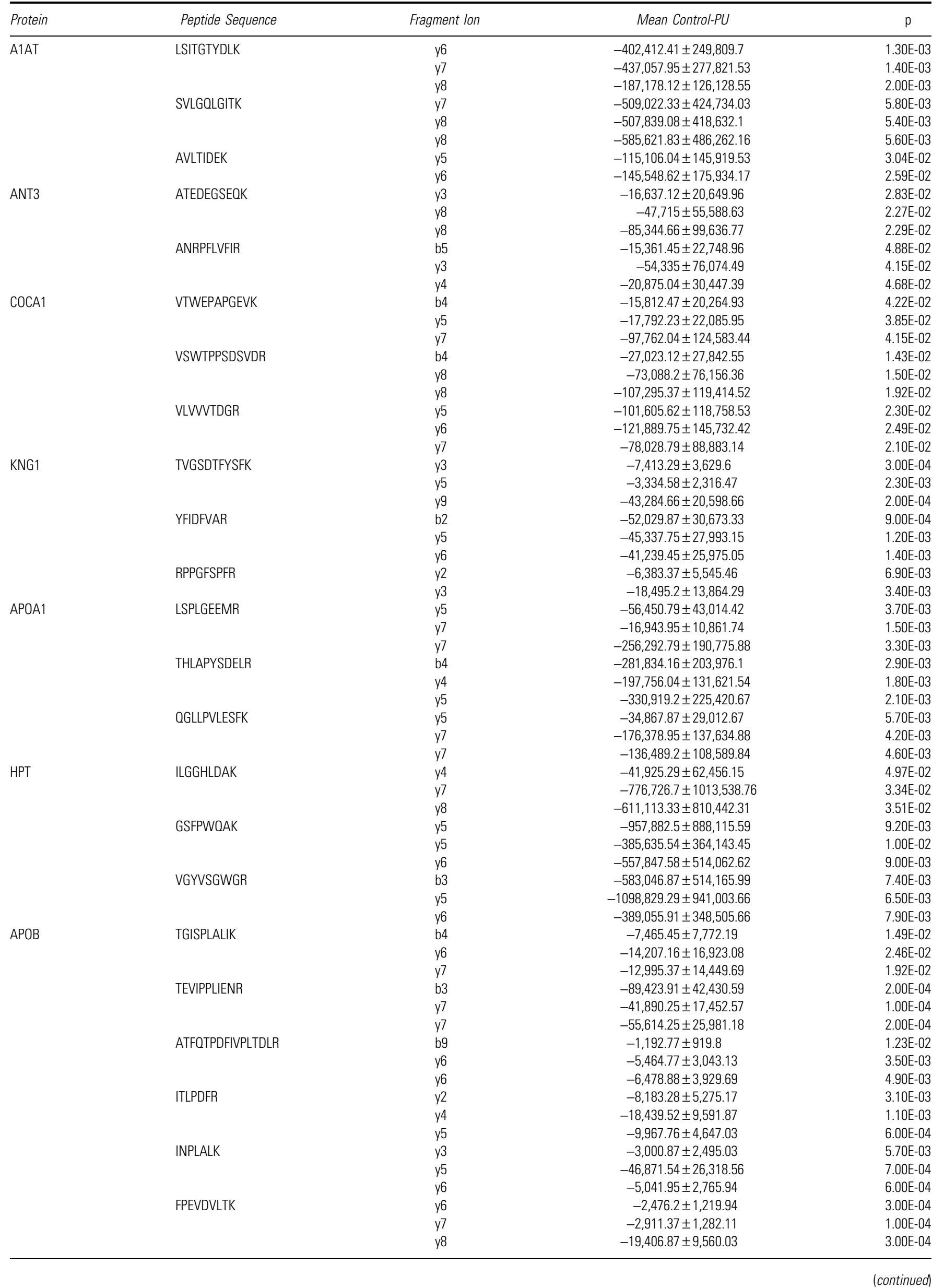


Table 3. (Continued)

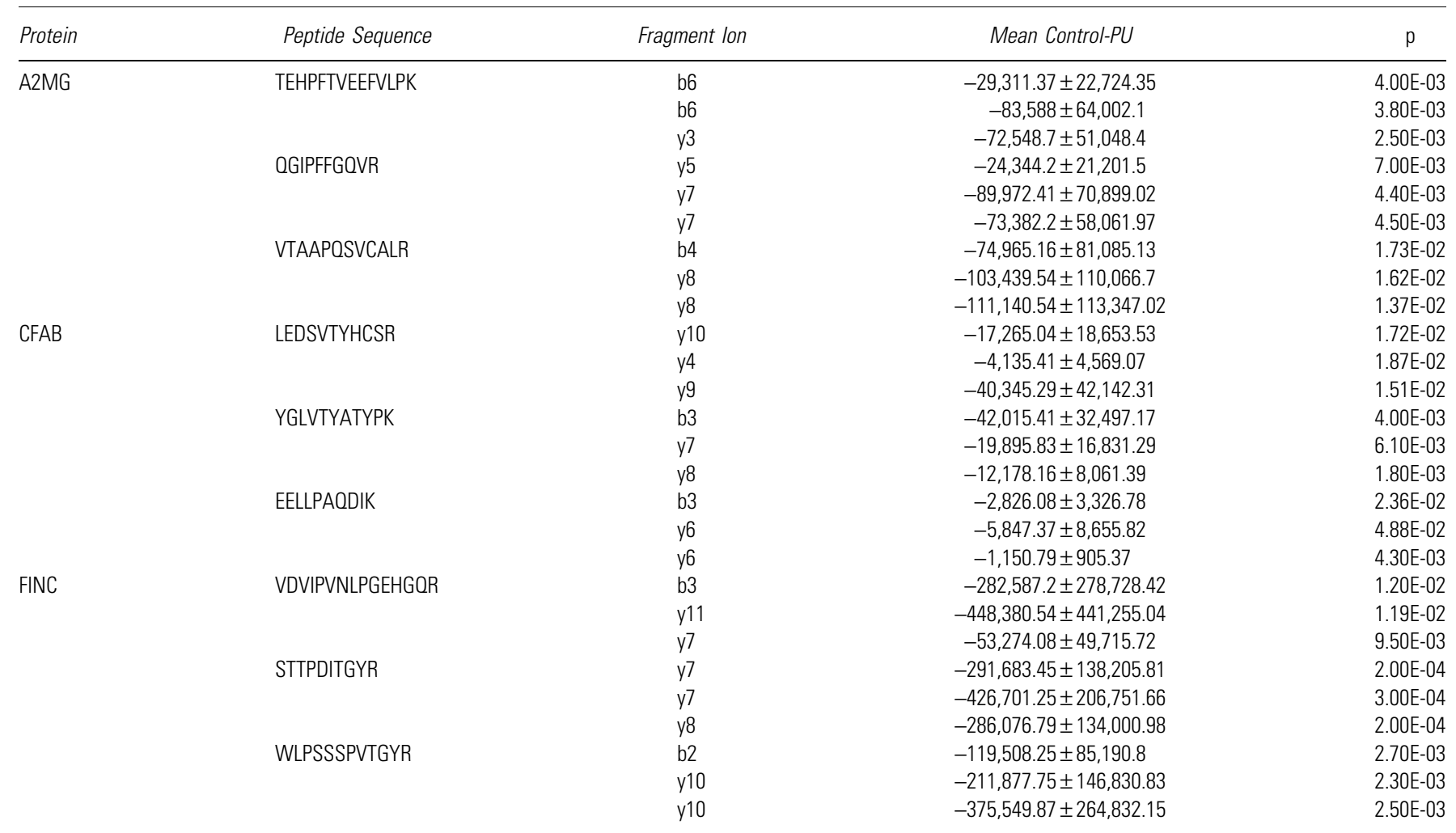

The peptides and transitions measured for each protein and the statistical analyses for each transition, including mean and $p$-value. C, Control; PU, pressure ulcer.

Table 4. List of protein monitored by selected reaction monitoring including the experimental parameters

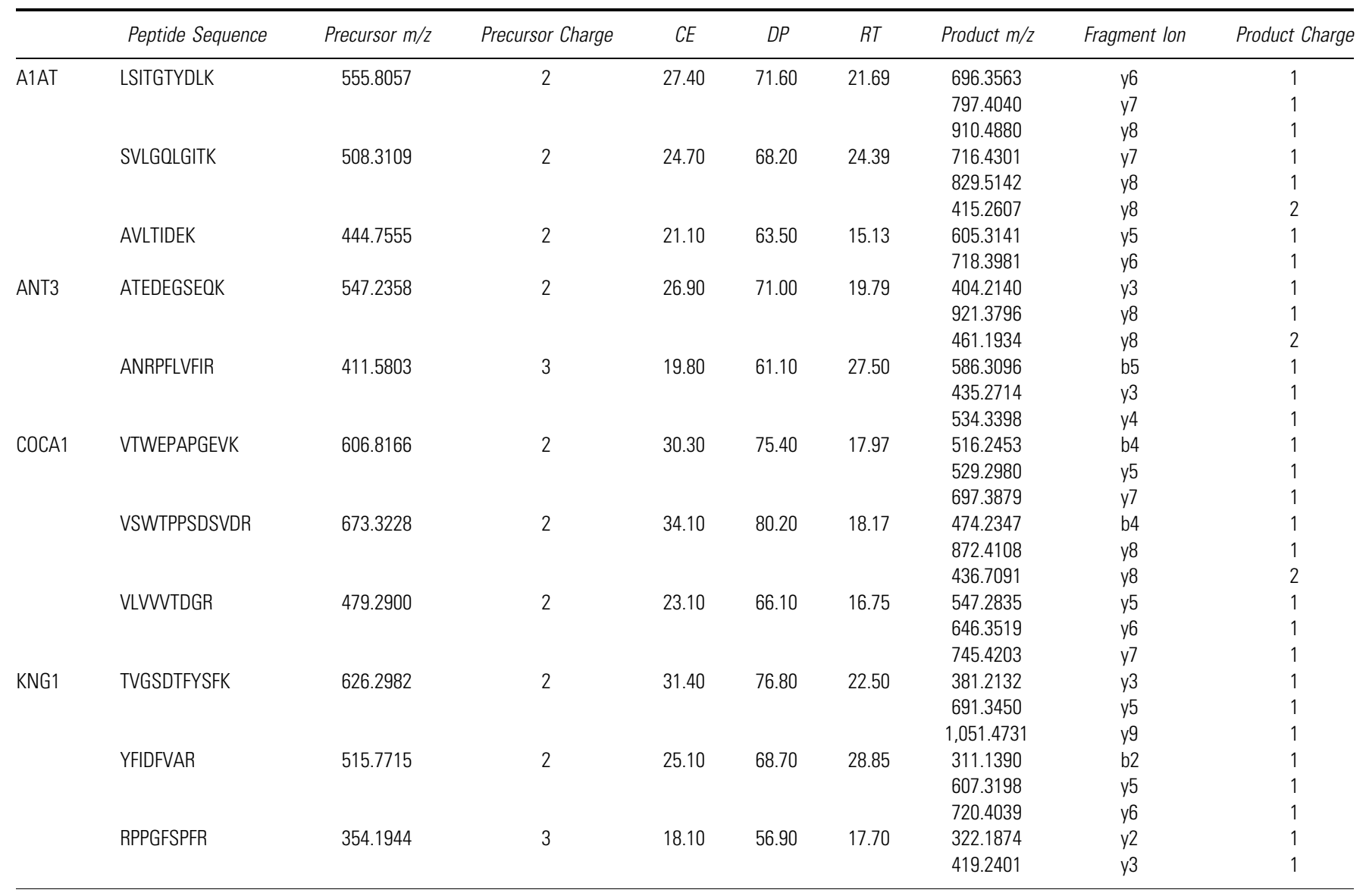


Table 4. (Continued)

\begin{tabular}{|c|c|c|c|c|c|c|c|c|c|}
\hline & Peptide Sequence & Precursor $\mathrm{m} / \mathrm{z}$ & Precursor Charge & $C E$ & $D P$ & $R T$ & Product $\mathrm{m} / \mathrm{z}$ & Fragment lon & Product Charge \\
\hline \multirow[t]{9}{*}{ APOA1 } & LSPLGEEMR & 516.2631 & 2 & 25.20 & 68.80 & 17.84 & 621.2661 & y5 & 1 \\
\hline & & & & & & & 831.4029 & y7 & 1 \\
\hline & & & & & & & 416.2051 & y7 & 2 \\
\hline & THLAPYSDELR & 434.5543 & 3 & 20.60 & 62.80 & 15.40 & 423.2350 & b4 & 1 \\
\hline & & & & & & & 532.2726 & y4 & 1 \\
\hline & & & & & & & 619.3046 & y5 & 1 \\
\hline & QGLLPVLESFK & 615.8583 & 2 & 30.80 & 76.00 & 34.59 & 623.3399 & y5 & 1 \\
\hline & & & & & & & 819.4611 & y7 & 1 \\
\hline & & & & & & & 410.2342 & y7 & 2 \\
\hline \multirow[t]{9}{*}{ HPT } & ILGGHLDAK & 308.5151 & 3 & 16.60 & 53.60 & 12.09 & 446.2609 & y4 & 1 \\
\hline & & & & & & & 349.1850 & y7 & 2 \\
\hline & & & & & & & 405.7271 & y8 & 2 \\
\hline & GSFPWQAK & 460.7349 & 2 & 22.00 & 64.70 & 21.15 & 629.3406 & y5 & 1 \\
\hline & & & & & & & 315.1739 & y5 & 2 \\
\hline & & & & & & & 388.7081 & y6 & 2 \\
\hline & VGYVSGWGR & 490.7511 & 2 & 23.70 & 66.90 & 18.31 & 320.1605 & b3 & 1 \\
\hline & & & & & & & 562.2732 & y5 & 1 \\
\hline & & & & & & & 661.3416 & y6 & 1 \\
\hline \multirow[t]{18}{*}{$\mathrm{APOB}$} & TGISPLALIK & 506.8237 & 2 & 24.60 & 68.10 & 28.98 & 359.1925 & b4 & 1 \\
\hline & & & & & & & 654.4549 & y6 & 1 \\
\hline & & & & & & & 741.4869 & y7 & 1 \\
\hline & TEVIPPLIENR & 640.8641 & 2 & 32.30 & 77.80 & 24.46 & 330.1660 & b3 & 1 \\
\hline & & & & & & & 838.4781 & y7 & 1 \\
\hline & & & & & & & 419.7427 & y7 & 2 \\
\hline & ATFOTPDFIVPLTDLR & 611.9964 & 3 & 26.10 & 75.70 & 37.36 & 511.2531 & b9 & 2 \\
\hline & & & & & & & 714.4145 & y6 & 1 \\
\hline & & & & & & & 357.7109 & y6 & 2 \\
\hline & ITLPDFR & 431.2451 & 2 & 20.30 & 62.60 & 24.66 & 322.1874 & y2 & 1 \\
\hline & & & & & & & 534.2671 & y4 & 1 \\
\hline & & & & & & & 647.3511 & y5 & 1 \\
\hline & INPLALK & 384.7525 & 2 & 17.70 & 59.20 & 19.12 & 331.2340 & y3 & 1 \\
\hline & & & & & & & 541.3708 & y5 & 1 \\
\hline & & & & & & & 655.4137 & y6 & 1 \\
\hline & FPEVDVLTK & 524.2897 & 2 & 25.60 & 69.30 & 24.19 & 674.4083 & y6 & 1 \\
\hline & & & & & & & 803.4509 & y7 & 1 \\
\hline & & & & & & & 450.7555 & y8 & 2 \\
\hline \multirow[t]{9}{*}{ A2MG } & TEHPFTVEEFVLPK & 558.2909 & 3 & 24.40 & 71.80 & 28.64 & 713.3253 & b6 & 1 \\
\hline & & & & & & & 357.1663 & b6 & 2 \\
\hline & & & & & & & 357.2496 & y3 & 1 \\
\hline & QGIPFFGQVR & 574.8142 & 2 & 28.50 & 73.00 & 28.98 & 606.3358 & y5 & 1 \\
\hline & & & & & & & 850.4570 & y7 & 1 \\
\hline & & & & & & & 425.7321 & y7 & 2 \\
\hline & VTAAPOSVCALR & 636.8401 & 2 & 32.00 & 77.50 & 15.27 & 343.1976 & b4 & 1 \\
\hline & & & & & & & 930.4826 & y8 & 1 \\
\hline & & & & & & & 465.7449 & y8 & 2 \\
\hline \multirow[t]{9}{*}{ CFAB } & LEDSVTYHCSR & 456.2067 & 3 & 21.20 & 64.40 & 8.92 & 627.2644 & y10 & 2 \\
\hline & & & & & & & 559.2405 & y4 & 1 \\
\hline & & & & & & & 562.7431 & y9 & 2 \\
\hline & YGLVTYATYPK & 638.3346 & 2 & 32.10 & 77.70 & 22.23 & 334.1761 & b3 & 1 \\
\hline & & & & & & & 843.4247 & y7 & 1 \\
\hline & & & & & & & 942.4931 & y8 & 1 \\
\hline & EELLPAODIK & 578.3164 & 2 & 28.70 & 73.30 & 19.39 & 372.1765 & b3 & 1 \\
\hline & & & & & & & 671.3723 & y6 & 1 \\
\hline & & & & & & & 336.1898 & y6 & 2 \\
\hline \multirow[t]{9}{*}{ FINC } & VDVIPVNLPGEHGQR & 543.9618 & 3 & 23.90 & 70.80 & 22.56 & 314.1710 & b3 & 1 \\
\hline & & & & & & & 602.3151 & y11 & 2 \\
\hline & & & & & & & 780.3747 & y7 & 1 \\
\hline & STTPDITGYR & 555.7749 & 2 & 27.40 & 71.60 & 14.86 & 821.4152 & y7 & 1 \\
\hline & & & & & & & 411.2112 & y7 & 2 \\
\hline & & & & & & & 461.7351 & y8 & 2 \\
\hline & WLPSSSPVTGYR & 675.3461 & 2 & 34.20 & 80.30 & 21.69 & 300.1707 & b2 & 1 \\
\hline & & & & & & & $1,050.5215$ & y10 & 1 \\
\hline & & & & & & & 525.7644 & $y 10$ & 2 \\
\hline
\end{tabular}

$\mathrm{CE}$, collision energy; $\mathrm{DP}$, declustering potential; $\mathrm{RT}$, retention time. 
A ENZYME REGULATOR ACTIVITY
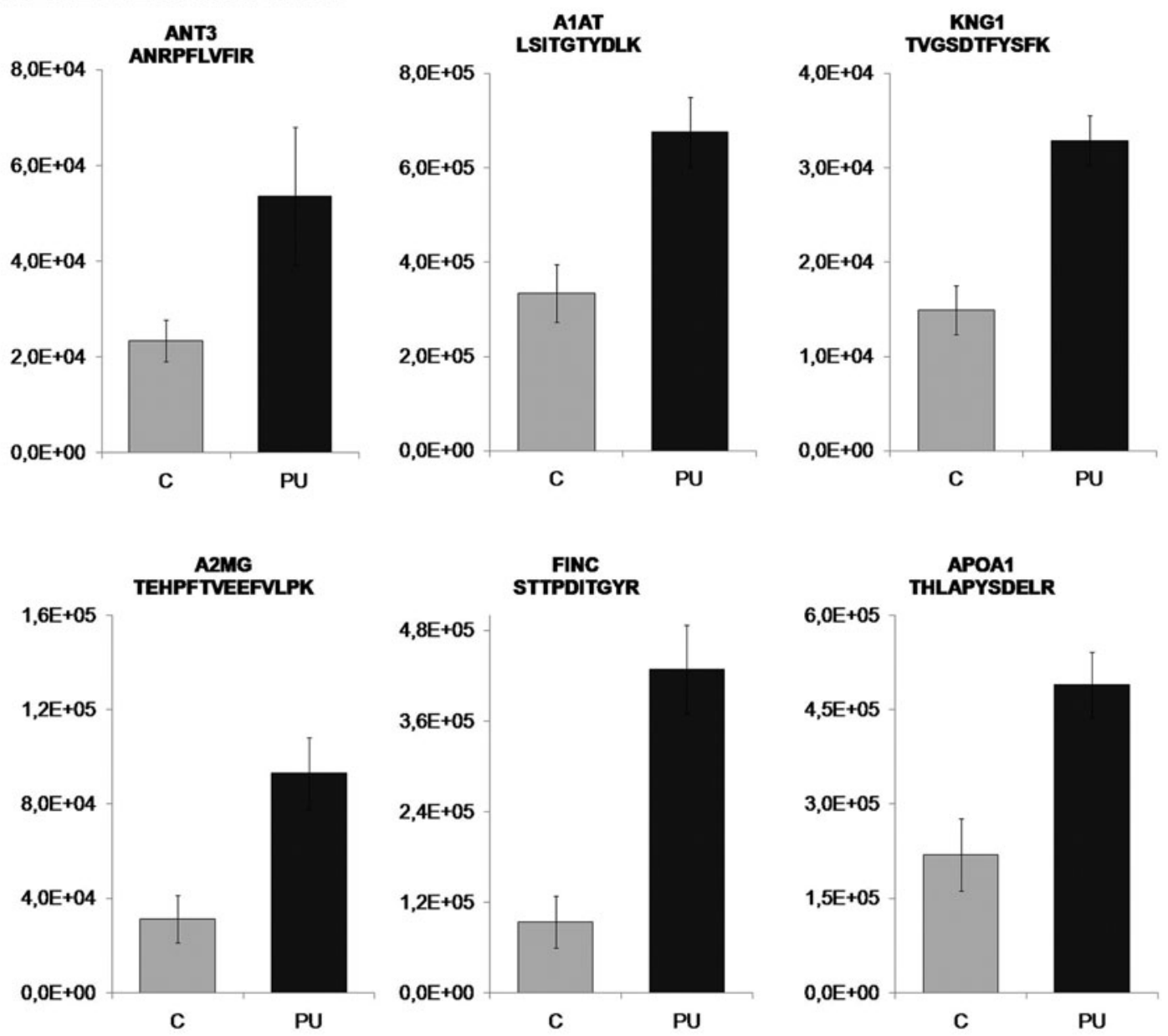

B

\section{OTHER PROTEINS}
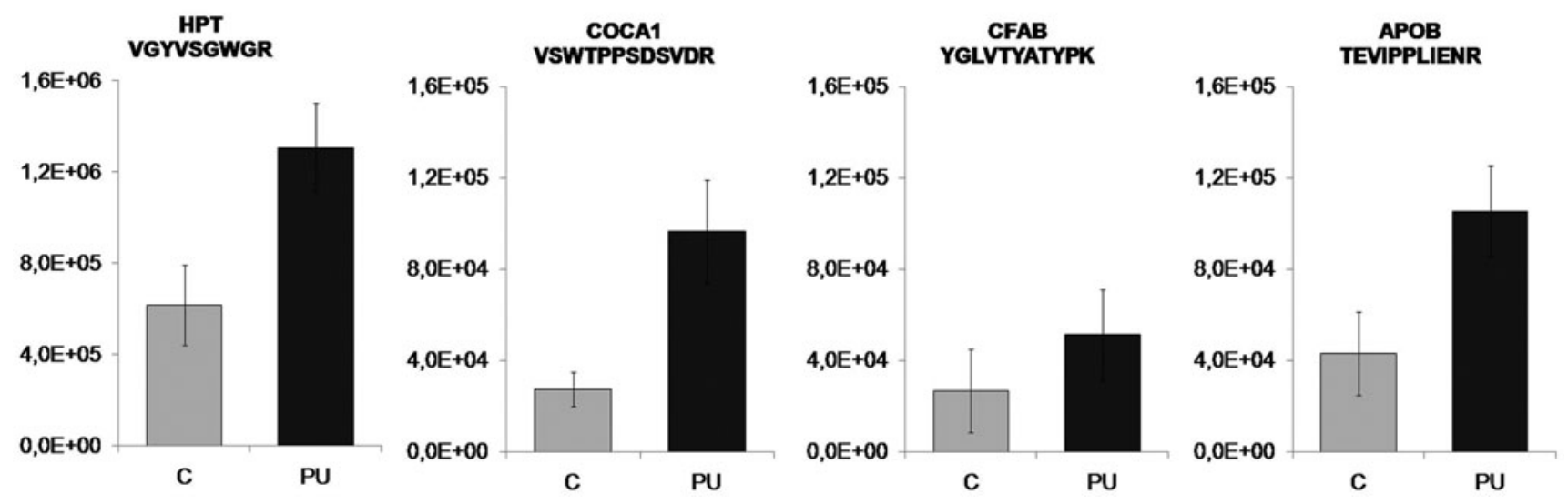

Figure 4. Verification of selected proteins showing increased abundance in PU than in control patients by SRM for (A) six enzyme regulator activity proteins, (B) other four proteins ( $p$-value is shown).

wound healing by accelerating resolution of inflammation through enhancing granulation tissue formation, involving increased endothelial progenitor cell incorporation, and by accelerating reepithelialization. ${ }^{66}$
In the context of PU pathology, other proteins more abundant in PU tissue included HPT, COCA1, CFAB, and APOB. Similar to the role of the inhibitors mentioned previously, HPT is a natural inhibitor of collagen degradation, ${ }^{67}$ and 


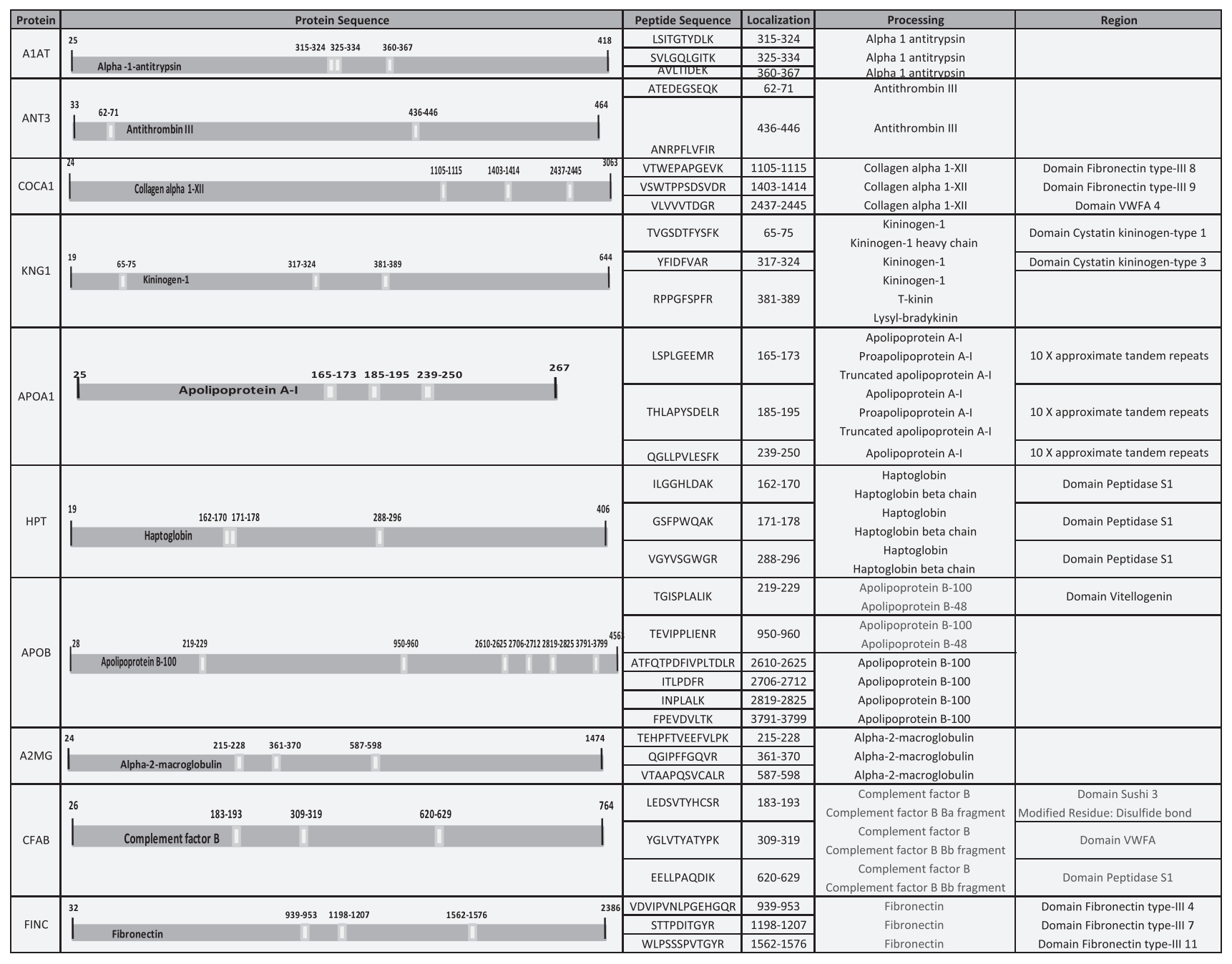

Figure 5. Localization of detected peptides in each protein used by SRM analysis. Table shows the position, in the complete amino acid sequence, of the detected peptides in each protein used for SRM analysis. All the detected peptides correspond to the mature protein. In addition, in some cases, some peptides correspond to some specific region, domain, or specific chain of the protein. ie) ILGGHLDAK, detected peptide in HPT, corresponds to mature protein (HPT), HPT beta chain, and domain peptidase S1. HPT, haptoglobin.

HPT
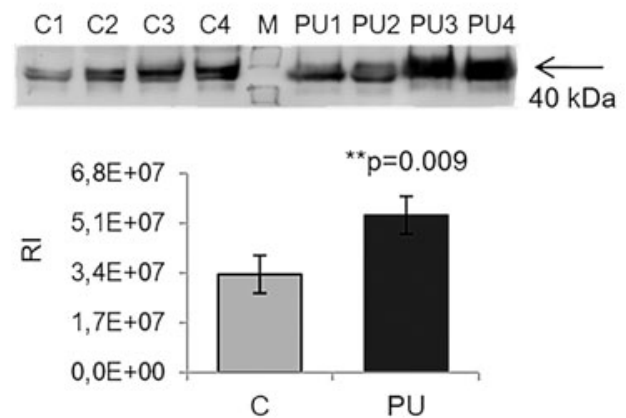

A1AT

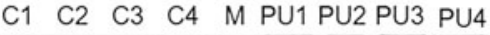
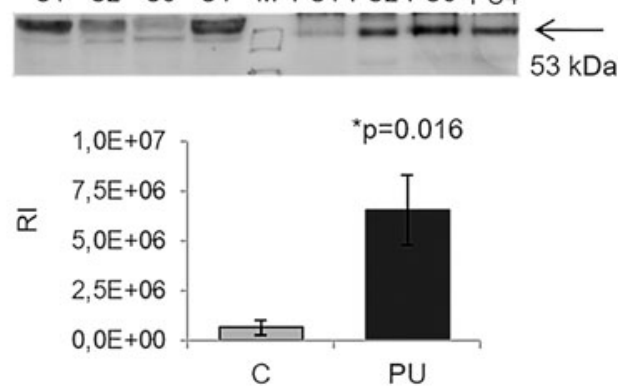

Figure 6. Verification of the differences observed with TMT labeling by western blotting. HPT and A1AT were analyzed by western blotting to confirm the reliability of SRM. ${ }^{*}$ and ${ }^{* *}$ showed statistical significance, ${ }^{*} p<0.05,{ }^{* *} p<0.01$. A1AT, alpha-1-antitrypsin; Rl, relative intensity. 
its increased levels may reflect a compensatory mechanism to maintain collagen within normal limits, enhanced collagen degradation is related to tissue destruction or malfunction. ${ }^{68,69}$ Indeed, we found more abundance of COCA1, which may indicate an acceleration of cutaneous collagen synthesis for ulcer recovery. ${ }^{70}$ Components such as CFAB are involved in complement activation, ${ }^{51,71,72}$ and play an important role in inflammatory conditions. ${ }^{28,73}$ Finally, in contrast to APOA1, APOB is the primary component of low-density lipoproteins and may stimulate wound healing by inducing interleukin- 8 secretion by fibroblasts. ${ }^{74,75}$

Overall, the results of our analysis suggest that damaged PU tissue is in the process of regeneration; however, these mechanisms are not sufficient to compensate for the pressure, friction, or shear forces that cause PUs. Typically, wound healing is defined by a complex interaction between proinflammatory cytokines, growth factors, proteases, and their inhibitors and extracellular components, which are in balance. In the setting of PUs, this balance is disrupted and the damage becomes chronic. In accordance, the proteins described in this study may have utility as new therapeutic options by supplementation, which may enhance the physiological response of wound healing.

\section{Study limitations}

The major limitation of this study was the relatively small number of samples obtained, and as such it was necessary to include two types of PUs in the study, grades 3 and 4 . Nonetheless, histological analysis indicated that both grades were largely similar, showing the absence of the epidermis layer as a result of the pressure produced in the lesion. To overcome the sample size limitation, we used two samples from ASIA B SCI patients in the verification phase, but the bulk of the work was performed with ASIA A SCI patients. Despite this limitation, patients were rigorously selected to be representative of elemental features such as age, sex, data of ASIA scale, advanced stage PU and metabolic control, in the case of diabetes. Finally, it is important to note that despite the reduced number of samples obtained, all experiments, in both discovery and verification phases were carried out with independent samples and not pools. Further studies are needed to prove the panel of biomarkers finding in this work and with higher sample size.

\section{INNOVATION}

Great efforts have been made in recent years to understand the mechanisms leading to the development of PUs in patients with SCI. The identification of new protein patterns involved in the pathogenesis of PUs may lead to better treatment and new therapeutic interventions. In this innovative study, we analyzed, to the best of our knowledge, for the first time, differential protein abundance of PU tissue from SCI patients using high-throughput protein identification and quantification by TMT followed by LC-MS/MS. We found 76 proteins with difference in abundance between PU and control tissue using TMT labeling. The proteins described in this article may have utility as new therapeutic options by supplementation, which may enhance the physiological response of wound healing.

\section{ACKNOWLEDGMENTS AND FUNDING SOURCES}

This work was supported by grants from the Instituto de Salud Carlos III (PI14/01917, PI18/00995, PT13/0001/0013) for Funding: ISCIII ("PI14/01917, PI18/00995, PT13/0001/0013)", co-funded by ERDF/ESF, "Investing in your future". Redes Temáticas de Investigación Cooperativa (FONDOS FEDER, RD12/0042/0071). Sociedad Española de Cardiología para la Investigación Básica 2017. Grant PRB3 (IPT17/0019-ISCIII-SGEFI/ERDF). These results are aligned with the Spanish initiative on the Human Proteome Project (SpHPP).

\section{AUTHOR DISCLOSURE AND GHOSTWRITING}

No competing financial interests exist. The authors listed expressly wrote the content of this article. No ghost writers were used to write this article.

\section{ABOUT THE AUTHORS}

Maria G. Barderas, PhD, is the principal investigator (PI) at the Department of Vascular Physiopathology at the Hospital Nacional de 
Parapléjicos (HNP), SESCAM, Toledo (Spain) since 2006 and subsequently the Coordinator of the Proteomics Platform until 2013. Laura MourinoAlvarez, PhD, is a postdoctoral researcher at the Department of Vascular Physiopathology at the HNP since 2015. Montserrat Baldan-Martin, PhD, is currently working at Hospital la Princesa. She performed her Doctoral thesis in the Department of Vascular Physiopathology at the HNP in 2017. Tatiana Martin-Rojas, PhD, works as postdoctoral researcher in the Department of Vascular Physiopathology at the HNP since 2016.
Nerea Corbacho-Alonso, MS, is performing the Doctoral thesis since 2016 in the Department of Vascular Physiopathology at the HNP. Juan Antonio Lopez, PhD, is a group leader of Proteomics Unit at CNIC Carlos III (Madrid) for several years. Tamara Sastre-Oliva, BS, is lab manager in the Laboratory of Vascular Physiopathology at the HNP since 2013. Felix Gil-Dones, PhD, is Associate Professor in Europea University (Madrid) since 2014. Jose Manuel Arevalo, MD, is Specialist on Reconstructive and Aesthetic Plastic Surgery at the HNP.

\section{REFERENCES}

1. Van Middendorp JJ, Goss B, Urquhart S, et al. Diagnosis and prognosis of traumatic spinal cord injury. Global Spine J 2011;1:1-8.

2. Charlifue S, Jha A, Lammertse D. Aging with spinal cord injury. Phys Med Rehabil Clin N Am 2010;21:383-402.

3. Chen $Y$, DeVivo MJ, Jackson AB. Pressure ulcer prevalence in people with spinal cord injury: ageperiod-duration effects. Arch Phys Med Rehabil 2005:86:1208-1213.

4. Caliri MH. Spinal cord injury and pressure ulcers. Nurs Clin North Am 2005;40:337-347.

5. Crenshaw R, Vistnes L. A decade of pressure sore research: 1977-1987. J Rehabil Res Dev 1989;26: 63-74.

6. Salzberg CA, Byrne DW, Cayten CG, et al. A new pressure ulcer risk assessment scale for individuals with spinal cord injury. Am J Phys Med Rehabil 1996;75:96-104.

7. Black J, Baharestani MM, Cuddigan J, et al. National Pressure Ulcer Advisory Panel's updated pressure ulcer staging system. Adv Skin Wound Care 2007;20:269-274

8. Bogie KM, Nuseibeh I, Bader DL. Early progressive changes in tissue viability in the seated spinal cord injured subject. Paraplegia 1995;33:141.

9. Bhattacharya S, Mishra RK. Pressure ulcers: current understanding and newer modalities of treatment. Indian J Plast Surg 2015;48:4-16.

10. Kirshblum SC, Burns SP, Biering-Sorensen F, et al. International standards for neurological classification of spinal cord injury (Revised 2011). J Spinal Cord Med 2011;34:535-546.

11. Werner T, Sweetman G, Savitski MF, et al. Ion coalescence of neutron encoded TMT 10-plex reporter ions. Anal Chem 2014;86:3594-3601.

12. Chahrour 0, Cobice D, Malone J. Stable isotope labelling methods in mass spectrometry-based quantitative proteomics. J Pharm Biomed Anal 2015;113:2-20.

13. Ahrné E, Glatter T, Viganò $\mathrm{C}$, et al. Evaluation and improvement of quantification accuracy in Isobaric
Mass Tag-based protein quantification experiments. J Proteome Res 2016;15:2537-2547.

14. Baldan-Martin M, Lopez JA, Corbacho-Alonso N, et al. Potential role of new molecular plasma signatures on cardiovascular risk stratification in asymptomatic individuals. Sci Rep 2018;8:4802.

15. Cardona M, López JA, Serafín A, et al. Executioner caspase- 3 and 7 deficiency reduces myocyte number in the developing mouse heart. PLoS One 2015;10:e0131411.

16. Martinez-Bartolome S, Navarro P, Martin-Maroto $F$, et al. Properties of average score distributions of SEQUEST. Mol Cell Proteomics 2008;7:11351145.

17. Navarro P, Vazquez J. A refined method to calculate false discovery rates for peptide identification using decoy databases. J Proteome Res 2009;8:1792-1796.

18. Bonzon-Kulichenko E, Garcia-Marques F, TrevisanHerraz M, Vazquez J. Revisiting peptide identification by high-accuracy mass spectrometry: problems associated with the use of narrow mass precursor Windows. J Proteome Res 2015;14: 700-710.

19. Mourino-Alvarez L, Baldan-Martin M, Sastre-Oliva $T$, et al. A comprehensive study of calcific aortic stenosis: from rabbit to human samples. Dis Models Mech 2018;11:dmm033423.

20. Martin-Rojas T, Mourino-Alvarez L, Gil-Dones F, et al. A clinical perspective on the utility of alpha 1 antichymotrypsin for the early diagnosis of calcific aortic stenosis. Clin Proteomics 2017;14:12.

21. Navarro P, Trevisan-Herraz M, Bonzon-Kulichenko E, et al. General statistical framework for quantitative proteomics by stable isotope labeling. J Proteome Res 2014;13:1234-1247.

22. Regan MA, Teasell RW, Wolfe DL, et al. A systematic review of therapeutic interventions for pressure ulcers following spinal cord injury. Arch Phys Med Rehabil 2009;90:213-231.

23. Garcia-Arguello LY, O'Horo JC, Farrell A, et al. Infections in the spinal cord-injured population: a systematic review. Spinal Cord 2016;55:526.
24. Wyffels JT, Fries KM, Randall JS, et al. Analysis of pressure ulcer wound fluid using two-dimensional electrophoresis. Int Wound J 2010;7:236-248.

25. Edsberg LE, Wyffels JT, Brogan MS, Fries KM. Analysis of the proteomic profile of chronic pressure ulcers. Wound Repair Regen 2012;20:378-401.

26. Taverna D, Pollins AC, Sindona G, Caprioli RM Nanney LB. Imaging mass spectrometry for assessing cutaneous wound healing: analysis of pressure ulcers. J Proteome Res 2015;14:986-996.

27. Edsberg LE, Wyffels JT, Ogrin R, Craven BC, Houghton P. A pilot study evaluating protein abundance in pressure ulcer fluid from people with and without spinal cord injury. J Spinal Cord Med 2015;38:456-467.

28. Eming SA, Martin P, Tomic-Canic M. Wound repair and regeneration: mechanisms, signaling, and translation. Sci Transl Med 2014;6:265sr266.

29. Sun BK, Siprashvili Z, Khavari PA. Advances in skin grafting and treatment of cutaneous wounds. Science 2014;346:941-945.

30. Falanga V. Wound healing and its impairment in the diabetic foot. Lancet 2005;366:1736-1743.

31. McCarty SM, Percival SL. Proteases and delayed wound healing. Adv Wound Care 2013;2:438-447.

32. Schreml S, Szeimies RM, Prantl L, et al. Oxygen in acute and chronic wound healing. Br J Dermatol 2010;163:257-268.

33. Dhall S, Do DC, Garcia M, et al. Generating and reversing chronic wounds in diabetic mice by manipulating wound redox parameters. J Diabetes Res 2014;2014:562625.

34. Bourguignon LY. Matrix hyaluronan-activated CD44 signaling promotes keratinocyte activities and improves abnormal epidermal functions. Am J Pathol 2014;184:1912-1919.

35. Cook H, Stephens P, Davies KJ, Thomas DW, Harding KG. Defective extracellular matrix reorganization by chronic wound fibroblasts is associated with alterations in TIMP-1, TIMP-2, and MMP-2 activity. J Invest Dermatol 2000;115:225233. 
36. Telgenhoff D, Shroot B. Cellular senescence mechanisms in chronic wound healing. Cell Death Differ 2005;12:695.

37. Wall IB, Moseley R, Baird DM, et al. Fibroblast dysfunction is a key factor in the non-healing of chronic venous leg ulcers. J Invest Dermatol 2008; 128:2526-2540.

38. Ennis WJ, Sui A, Bartholomew A. Stem cells and healing: impact on inflammation. Adv Wound Care 2013;2:369-378.

39. Cianfarani F, Toietta G, Di Rocco G, et al. Diabetes impairs adipose tissue-derived stem cell function and efficiency in promoting wound healing Wound Repair Regen 2013;21:545-553.

40. Rodriguez-Menocal L, Salgado M, Ford D, Van Badiavas E. Stimulation of skin and wound fibroblast migration by mesenchymal stem cells derived from normal donors and chronic wound patients. Stem Cells Transl Med 2012;1:221-229.

41. Mast BA, Schultz GS. Interactions of cytokines, growth factors, and proteases in acute and chronic wounds. Wound Repair Regen 1996;4:411-420.

42. Yager DR, Nwomeh BC. The proteolytic environment of chronic wounds. Wound Repair Regen 1999;7:433-441.

43. Ladwig GP, Robson MC, Liu RAN, et al. Ratios of activated matrix metalloproteinase-9 to tissue inhibitor of matrix metalloproteinase-1 in wound fluids are inversely correlated with healing of pressure ulcers. Wound Repair Regen 2002;10:26-37.

44. Al-Omari M, Korenbaum E, Ballmaier $M$, et al. Acute-phase protein $\alpha 1$-antitrypsin inhibits neutrophil calpain I and induces random migration Mol Med 2011;17:865-874.

45. Opal SM. Interactions between coagulation and inflammation. Scand J Infect Dis 2003;35:545-554.

46. Roemisch J, Gray E, Hoffmann JN, Wiedermann CJ. Antithrombin: a new look at the actions of a serine protease inhibitor. Blood Coagul Fibrinolysis 2002;13:657-670.

47. Levy J, Sniecinski R, Welsby I, Levi M. Antithrombin: anti-inflammatory properties and clinical applications. Thromb Haemost 2016;115:712-728.

48. Kowal-Vern A, Orkin BA. Antithrombin in the treatment of burn trauma. World $\mathrm{J}$ Crit Care Med 2016:5:17-26.

49. Fujimoto M, Asano Y, Ishii T, et al. The wound/burn guidelines-4: guidelines for the management of skin ulcers associated with connective tissue disease/vasculitis. J Dermatol 2016;43:729-757.

50. Browse NL, Burnand KG. The cause of venous ulceration. Lancet 1982;320:243-245

51. Schmidtchen A. Degradation of antiproteinases, complement and fibronectin in chronic leg ulcers. Acta Derm Venereol 2000:80:179-184.

52. Müller K, Elverland A, Romner B, et al. Analysis of protein $\mathrm{S}-100 \mathrm{~B}$ in serum: a methodological study. Clin Chem Lab Med 2006;44:1111-1114.

53. Muller-Esterl W. Human kininogens. Methods Enzymol 1988;163:240-256.
54. Grinnell F, Zhu M. Fibronectin degradation in chronic wounds depends on the relative levels of elastase, alpha1-proteinase inhibitor, and alpha2-macroglobulin. J Invest Dermatol 1996;106:335-341.

55. Pankov R, Yamada KM. Fibronectin at a glance. J Cell Sci 2002;115:3861-3863.

56. Zhu J, Clark RA. Fibronectin at select sites binds multiple growth factors (GF) and enhances their activity: expansion of the collaborative ECM-GF paradigm. J Invest Dermatol 2014;134:895-901.

57. Clark RA, Lanigan JM, DellaPelle P, et al. Fibronectin and fibrin provide a provisional matrix for epidermal cell migration during wound reepithelialization. J Invest Dermatol 1982;79:264-269.

58. Martino M, Tortelli F, Mochizuki M, et al. Engineering the growth factor microenvironment with fibronectin domains to promote wound and bone tissue healing. Sci Transl Med 2011;3: 100ra89.

59. Tortelli F, Pisano M, Briquez P, Martino M, Hubbell J. Fibronectin binding modulates CXCL11 activity and facilitates wound healing. PLoS One 2013:8:e79610

60. Greenhalgh DG, Sprugel KH, Murray MJ, Ross R. PDGF and FGF stimulate wound healing in the genetically diabetic mouse. Am J Pathol 1990; 136:1235-1246.

61. Nissen NN, Polverini PJ, Koch AE, et al. Vascular endothelial growth factor mediates angiogenic activity during the proliferative phase of wound healing. Am J Pathol 1998;152:1445-1452.

62. Johnson MB, Pang B, Gardner DJ, et al. Topical fibronectin improves wound healing of irradiated skin. Sci Rep 2017;7:3876.

63. Van Craeyveld E, Gordts S, Jacobs F, De Geest B. Gene therapy to improve high-density lipoprotein metabolism and function. Curr Pharm Des 2010;16: 1531-1544.

64. Duffy D, Rader DJ. Update on strategies to increase HDL quantity and function. Nat Rev Cardiol 2009:6:455

65. Jiang $Y$, Wang $X$, Xia $L$, et al. A cohort study of diabetic patients and diabetic foot ulceration patients in China. Wound Repair Regen 2015;23:222230.

66. Gordts SC, Muthuramu I, Amin R, Jacobs F, Geest $B D$. The Impact of lipoproteins on wound healing: topical HDL therapy corrects delayed wound healing in apolipoprotein $\mathrm{E}$ deficient mice. Pharmaceuticals 2014:7:419-432.

67. Smeets MB, Fontijn J, Kavelaars A, Pasterkamp G, De Kleijn DP. The acute phase protein haptoglobin is locally expressed in arthritic and oncological tissues. Int J Exp Pathol 2003;84:69-74.

68. Jackson C, Nguyen M, Arkell J, Sambrook P. Selective matrix metalloproteinase (MMP) inhibition in rheumatoid arthritis - targetting gelatinase A activation. Inflamm Res 2001;50:183-186.

69. Westermarck J, Kähäri V-M. Regulation of matrix metalloproteinases expression in tumor invasion. FASEB J 1999;13:781-792.
70. Fang $W$, Wang G, Tang $L$, et al. Hydrogen gas inhalation protects against cutaneous ischaemia/ reperfusion injury in a mouse model of pressure ulcer. J Cell Mol Med 2018;22:4243-4252.

71. Riihilä $P$, Nissinen L, Farshchian $M$, et al. Complement component $\mathrm{C} 3$ and complement factor $\mathrm{B}$ promote growth of cutaneous squamous cell carcinoma. Am J Pathol 2017;187:1186-1197.

72. Liu J, Hoh J. Loss of complement factor $\mathrm{H}$ in plasma increases endothelial cell migration. $J$ Cancer 2017;8:2184-2190

73. Zhao R, Liang $H$, Clarke E, Jackson C, Xue M. Inflammation in chronic wounds. Int $\mathrm{J}$ Mol Sci 2016;17:2085

74. Dobreva I, Waeber G, James RW, Widmann C. Interleukin-8 secretion by fibroblasts induced by low density lipoproteins is p38 MAPK-dependent and leads to cell spreading and wound closure. $J$ Biol Chem 2006;281:199-205.

75. Bulat N, Waeber G, Widmann C. LDLs stimulate p38 MAPKs and wound healing through SR-B independently of Ras and PI3 kinase. J Lipid Res 2009:50:81-89

\section{Abbreviations and Acronyms}

$\mathrm{A} 1 \mathrm{AT}=$ alpha-1-antitrypsin

$\mathrm{A} 2 \mathrm{MG}=$ alpha-2-macroglobulin

$\mathrm{ACN}=$ acetonitrile

ANT3 $=$ antithrombin-III

APOA1 = apolipoprotein A-I

$\mathrm{APOB}=$ apolipoprotein $\mathrm{B}$

$A S I A=$ American Spinal Injury Association

$A U C=$ area under the curve

$B S A=$ bovine serum albumin

CFAB $=$ complement factor $\mathrm{B}$

$\mathrm{CE}=$ collision energy

$\mathrm{DTT}=$ dithiothreitol

$\mathrm{DP}=$ declustering potential

$F A=$ formic acid

$\mathrm{FDR}=$ false discovery rate

FINC $=$ fibronectin

$\mathrm{H} \& \mathrm{E}=$ hematoxylin and eosin

$\mathrm{HDL}=$ high-density lipoproteins

HPT $=$ haptoglobin

IAA $=$ iodoacetamide

KNG1 $=$ kininogen-1

LC-MS/MS = liquid chromatography tandem mass spectrometry

MMTS $=$ methyl methanethiosulfonate

$\mathrm{PBS}=$ phosphate-buffered saline

PUs $=$ pressure ulcers

$\mathrm{RI}=$ relative intensity

$\mathrm{RT}=$ retention time

$\mathrm{SCl}=$ spinal cord injury

SDS $=$ sodium dodecyl sulfate

SRM $=$ selected reaction monitoring

STRING $=$ search tool for the retrieval of interacting genes/proteins

TCEP = Tris(2-carboxyethyl) phosphine hydrochloride

TEAB $=$ triethylammonium bicarbonate

TFA $=$ trifluoroacetic acid

TMT $=$ tandem mass tags

WSPP $=$ weighted spectrum peptide and the protein 